\title{
DESKRIPSI PRAKTIK OKULTISME DI KALANGAN REMAJA SUKU DAYAK MAANYAN DI GEREJA SIDANG-SIDANG JEMAAT ALLAH (GSJA) WILAYAH KABUPATEN BARITO TIMUR KALIMANTAN TENGAH
}

\author{
Demsy Jura \\ Wellem Sairwona \\ Universitas Kristen Indonesia \\ demsy.jura@uki.ac.id \\ wellem.sairwona@uki.ac.id
}

\begin{abstract}
Abstrak
Pulau Kalimantan merupakan salah satu pulau besar yang ada di Indonesia, dan wilayah yang didiami oleh masyarakat suku Dayak ini sangat kental dengan tradisi keyakinan tradisonal dengan berbagai upacara keagamaan yang ada. Agama asli orang Dayak adalah Kaharingan, dan dalam kepercayaan agama ini, sosok Tuhan berbeda sebutannya karena bergantung pada wilayah, misalnya untuk kawasan Barito, Tuhan Kaharingan disebut Yustu Ha Latalla, sedangkan di Kotawaringin Barat disebut Sanghyang Dewata. Namun demikian, mayoritas pemeluk Kaharingan menyebut pencipta sebagai Ranying Hatalla Langit yang kalau diartikan adalah Kuasa yang Maha Besar. Dalam kehidupan kesehariannya, masyarakat Dayak percaya kepada roh-roh inilah yang di-yakini dengan kuar; walaupun kekristenan telah menjadi bagian dari kehidupan mereka. Orang Dayak yang terdiri dari sejumlah sub-suku; memiliki tradisi leluhur yang seringkali terhubung dengan penyembahan pada roh-roh leluhur.

Secara khusus masyarakat Dayak Maayan, beberapa istilah yang berhubungan dengan penyembahan terhadap roh leluhur, diantaranya: Wadian atau Balian yaitu orang yang menjadi pemimpin ritual dalam beberapa upacara adat Dayak. Damang atau Damung adalah pemimpin atau tokoh masyarakat adat Dayak Maanyan. Mantir adalah tetua adat atau kepala suku atau kepala adat yang dihormati di tengah masyarakat Dayak Maanyan. Wadian Matei adalah pemimpin ritual dalam upacara kematian suku Dayak Maanyan. Wadian Welum adalah pemimpin ritual dalam upacara pengucapan syukur. Datu Tunyung adalah surga dalam kepercayaan suku Dayak Maanyan. Talamana Tuah Hukat adalah Tuhan dalam kepercayaan suku Dayak Maanyan dan juga sering di-sebut Alatala. Kariau adalah roh-roh atau makhluk halus. Adiau adalah roh orang yang sudah me-ninggal. Kebanyakan orang Dayak Maayan masih setia menjalankan tradisi leluhur itu. Demikian juga dengan sejumlah ritual keagamaan seperti Ipaket. Masyarakat Dayak Maanyan percaya bahwa kematian adalah sebuah awal perpindahan atau perjalanan roh (adiau atau amirue) ke kemuliaan dunia baru (tumpuk adiau) yang subur, damai, tentram, kaya raya di mana di sana ada kesempurnaan. Itulah sebabnya ada upacara khusus bagi mereka yang meninggal dunia. Upacara kematian yang lengkap dalam tradisi Suku Dayak Maanyan disebut Marabia, Ijambe dan Ngadatonuntuk. Upacara ini
\end{abstract}


harus di-laksanakan secara lengkap menurut adat agar sampai ke Datu Tunyung atau sorga; dan jika tidak dilakukan secara lengkap, maka arwah atau adiau bisa gentayangan, dan hal inilah yang ditakuti oleh mereka yang masih hidup

Kehadiran gereja di kalangan Dayak Maayan, sedikit memberi perubahan dalam pola pikir mereka. Upacara yang berkaitan dengan penyembahan terhadap leluhur mulai disentuh dengan kebenaran Alkitab. Bahaya akan praktik Okultisme terus disampaikan, namun hal itu juga terus berlangsung. Itulah sebabnya penelitian ini hendak menyampaikan data mengenai deskripsi praktik Okultisme yang dilakukan para remaja gereja di Gereja Sidang Jemaat Allah. Penelitian ini hendak membuktikan hal apa saja yang dipraktikkan dan seberapa besar peran gereja dalam membina kehidupan rohani anggota jemaatnya.

Kata Kunci: Deskripsi, Okultisme, Agama Kaharingan, Remaja

\section{Pendahuluan}

\subsection{Latar Belakang Masalah}

Kalimantan adalah salah satu pulau yang masuk dalam yuridiksi wilayah Negara Kesatuan Republik Indonesia; walaupun bagian utara sebagian masuk dalam wilayah Sabah dan Serawak yang termasuk dalam yuridiksi Malaysia. Pulau ini memiliki luas sekitar 535.834 kilometer persegi, dan terdiri dari daerah pegunungan atau perbukitan sekitar $39,69 \%$, daratan dengan luar 35,08\%, pantai $11,73 \%$, dataran aluvial seluas 12,47\%, dan lain-lain sekitar $0,93 \%$. $^{1}$ Sungai-sungai besar terdapat di pulau ini, dan salah satunya adalah sungai Kapuas di Kalimantan Barat dengan panjang $1.143 \mathrm{~km}$., dan kekayaan sumber daya alam yang sedemikian besar nyata di pulau terbesar di Indonesia, dan hasil per-tambangan serta kehutanan masih men-jadi primadona di pulau ini.

Walaupun terdapat beberapa kelompok masyarakat yang mendiami Kalimantan, namun mayoritas penduduk

\footnotetext{
${ }^{1}$ https://id.wikipedia.org/wiki/Kalimantan _Tengah,diakses pada hari Senin, 2 Juli 2018, Pkl. 15.35 WIB.
}

pulau ini adalah suku Dayak. Dugaan kuat bahwa orang Dayak merupakan mayoritas penduduk pulau Kalimantan berasal dari Yunnan, daratan Asia Tengah. Mereka datang dalam beberapa gelombang migrasi pada zaman glasial atau zaman es, sekitar 3000-1500 Sebelum Masehi. Diperkirakan bahwa perjalanan migrasi mereka melalui daratan semenajung Malaysia, kemudian ke Sumatra, Jawa, terus ke kepulauan Filipina, dan Hainan serta Taiwan (formosa). ${ }^{2}$ Kesamaan fisik dan kebudayaan beberapa sub suku Dayak yang memiliki ciri ras mongoloid, dan juga teori tentang Migrasi Proto Melayu atau Melayu Tua di mana terjadi migrasi dari Yunnan Cina ke nusantara dan terjadi pada rentang waktu 2500-1500 tahun Sebelum Masehi; merupakan hal yang wajar untuk dimaklumi. ${ }^{3}$ Perhatikan terjadi selisih perbedaan tahun migrasi orang Dayak antara Hilman Hadikusuma dan Neil Joseph

\footnotetext{
${ }^{2}$ Hilman Hadikusuma, Antropologi Hukum Indonesia, (Bandung: Alumni, 1986), h. 183.

${ }^{3}$ Neil Joseph Ryan, A History of Malaysia and Singapore, (London: Oxford University Press. 1976), h. 4-5.
} 
Ryan sekitar 500 tahun, dan hal itu tidak terlalu dipermasalahkan karena keduanya berpegang pada sejarah yang tidak banyak didukung dengan data memadai. M. Umberen, dalam buku Sejarah Kebudayaan Kalimantan, mengatakan bahwa:

Suku asli di Kalimantan Tengah di-sebut suku Dayak, Kaharingan lebih dikenal sebagai keyakinan orang Dayak dan dengan lekatnya keyakin-an dan kepercayaan itu sehingga seolah-olah sebagai agama aslinya. Pada zaman dahulu tidak semua orang dayak menamakan kepercaya-an tersebut sebagai Kaharingan, namun sebagian mengatakan sebagai Agama Helu/Dahulu (awal) dan agama Dusun bahkan ada yang menyebutnya sebagai agama Dayak. Akan tetapi dari sekian banyaknya istilah untuk menamakan kepercayaan tersebut hanya kaharinganlah yang tepat. ${ }^{4}$

Agama asli orang Dayak adalah Ka-haringan, dan dalam kepercayaan agama ini, sosok Tuhan berbeda sebutannya karena bergantung pada wilayah, misal-nya untuk kawasan Barito, Tuhan Kaharingan disebut Yustu Ha Latalla, sedangkan di Kotawaringin Barat disebut Sanghyang Dewata. Namun demikian, mayoritas pemeluk Kaharingan menyebut pencipta sebagai Ranying Hatalla Langit yang kalau diartikan adalah Kuasa yang Maha Besar. Syamsir Salam, dalam buku: Agama Kaharigan: Akar-Akar Budaya Suku Dayak di Kalimantan Tengah, mengatakan:

Kepercayaan yang berlaku umum dalam masyarakat Dayak adalah roh para leluhur, di mana orang Dayak percaya dengan mahluk gaib; yang

\footnotetext{
${ }^{4}$ M. Umberen, Sejarah Kebudayaan Kalimantan, (Jakarta: Penerbit Departemen Pendidikan Nasional, 1994), h. 63
}

oleh mereka dikelompokkan menjadi tiga, yaitu: Pertama, roh gaib yang menduduki tempat utama, seperti Ranying Hatalla Langit, Bawin Jata Balawang Bulau, serta beberapa pembantunya; Kedua, roh-roh gaib yang bersifat baik, seperti roh-roh nenek moyang mereka sendiri dan roh-roh orang yang meninggal dengan tenang atau mayat yang sudah dilakukan upacara tiwah; dan Ketiga roh-roh gaib yang bersifat jahat merupakan roh-roh yang tidak tahu darimana asalnya, roh-roh para leluhur yang mati penasaran, dan orang-orang yang meninggal yang terlambat atau tidak dilakukan upacara tiwah. ${ }^{5}$

Kepercayaan kepada roh-roh inilah yang diyakini teguh oleh sebagian masyarakat Dayak; walaupun kekristenan telah men-jadi bagian dari kehidupan mereka.

Sebelum agama Kristen masuk ke Kalimantan, para misionaris Katolik telah mengupayakan pendirian gereja di sana abad ke-17. Misionaris Katolik yang masuk ke wilayah Kalimantan Selatan adalah Ventimiglia yang kemudian terbunuh pada tahun 1691. Usaha Pekabar-an Injil dari kalangan Kristen dirintis oleh J. H. Barnstein yang diutus oleh badan misi dari Jerman. Kedatangan misionaris inilah yang menjadi tonggak sejarah Perkabaran Injil bagi masyarakat Dayak. Walaupun telah memeluk agama Kristen, banyak orang Dayak pada kenyataannya masih melaksanakan tradisi leluhur yang telah mereka anut sebelumnya. Tentunya

${ }^{5}$ Syamsir Salam, Agama Kaharigan: Akar-Akar Budaya Suku Dayak di Kalimantan Tengah, (Jakarta: Lembaga Penelitian UIN Syarif Hidayatullah Jakarta, 2009), h. 161.

${ }^{6}$ Th. Muller Kruger, Sejarah Gereja di Indonesia, (Jakarta: BPK. Gunung Mulia, 1966), h.145. 
penyembahan kepada para leluhur dan percaya akan roh-roh serta hal-hal gaib lainnya sangat nyata dalam kehidupan mereka, artinya masyarakat ini mempraktekkan pola kehidupan yang singkritisme.

Masyarakat Dayak yang mendiami wilayah Kalimantan Tengah Bagian Selatan, khususnya Kabupaten Barito Timur, masih memegang teguh kepercayaan warisan leluhur. Suku Dayak Maanyan yang mendiami wilayah ini masih memelihara tradisi nenek moyang dan bahkan keyakinan Kaharingan masih memberi pengaruh besar pada kehidupan masyarakat setempat. Masyakarat Dayak Maanyan yang dikenal memiliki peradaban maju sebab berdasarkan tradisi lisan setempat menyatakan bahwa suku Dayak Maanyan pernah yang mulanya mendiami wilayah Kalimantan Selatan itu pernah memiliki kerajaan bernama Nansarunai yang kemudian hancur karena diserbu oleh Kerajaan Majapahit.

Gambaran praktik Okultisme secara umum dalam kehidupan suku Dayak Ma'anyan dapat lihat dari berbagai bentuk upacara adat yang diselenggarakan oleh masyarakat secara rutin. Dugaan kuat masyarakat Dayak yang beragama Kristen ikut terlibat dalam berbagai ritual yang diduga rentan dengan penyembahan berhala. Adanya praktik okultisme di-kalangan Remaja di Gereja Sidang-Sidang Jemaat Allah (GSJA) Wilayah Kabupaten Barito Timur Kalimantan Tengah patut diamati dengan sungguh-sungguh. Gereja perlu bersikap tegas dan harus mampu memberikan pengajaran yang benar bagi orang Kristen, agar supaya tidak jatuh ke dalam dosa penyembahan berhala.

Walaupun masyarakat Dayak telah terjangkau oleh Injil, namun kebudayaan yang sedemikian kuat terkadang membuat mereka hidup berbeda dengan apa yang tertulis dalam Alkitab. Praktik penyembahan kepada para leluhur masih terus dilakukan hingga sekarang ini. Gereja mengalami kesulitan dalam menangani praktik okultisme di kalangan pemuda remaja di Gereja Sidang-Sidang Jemaat Allah (GSJA) Wilayah Kabupaten Barito Timur Kalimantan Tengah.

\subsection{Identifikasi Masalah}

Dari pemaparan mengenai latar belakang masalah di atas; nampak beberapa masalah yang dapat diidentifikasi sebagai berikut:

a. Masyarakat Dayak masih memegang teguh kepercayaan leluhur yang berkaitan penyembahan dengan rohroh nenek moyang.

b. Masyarakat Dayak yang sudah beragama Kristen masih melaksanakan tradisi leluhur yang berkaitan dengan penyembahan kepada roh-roh nenek moyang.

c. Praktek Okultisme dalam kehidupan masyarakat Dayak Maanyan dianggap sebagai hal yang biasa karena dipandang sebagai bagian dari tradisi yang diwariskan secara turun-temurun.

d. Gambaran praktik okultisme secara umum dalam kehidupan suku Dayak Maanyan dapat lihat dari berbagai bentuk upacara adat yang diselenggarakan oleh masyarakat secara rutin.

e. Adanya praktik okultisme di kalangan Pemuda Remaja di Gereja Sidang-Sidang Jemaat Allah (GSJA) Wilayah Kabupaten Barito Timur Kalimantan Tengah.

f. Gereja mengalami kesulitan dalam penangani praktik okultisme di kalangan pemuda remaja di Gereja Sidang-Sidang Jemaat Allah (GSJA) 
Wilayah Kabupaten Barito Timur Kalimantan Tengah.

\subsection{Batasan Masalah}

Berdasarkan identifikasi masalah yang disarikan dari latar belakang masalah yang diuraikan di atas dan mem-perhatikan kerumitan dan kompleksitas masalah maka masalah dibatasi sebagai berikut:

a. Gambaran praktik okultisme secara umum dalam kehidupan suku Dayak Maanyan?

b. Praktik okultisme di kalangan Pemuda Remaja di Gereja SidangSidang Jemaat Allah (GSJA) Wilayah Kabupaten Barito Timur Kalimantan Tengah.

c. Peran aktif gereja dalam menangani praktik okultisme pemuda remaja di Gereja Sidang-Sidang Jemaat Allah (GSJA) Wilayah Kabupaten Barito Timur Kalimantan Tengah.

\subsection{Rumusan Masalah}

Berdasarkan batasan masalah di atas, maka peneliti menetapkan rumusan masalah sebagai berikut:

a. Bagaimana gambaran praktik okultisme secara umum dalam kehidupan suku Dayak Maanyan?

b. Bagaimana praktik okultisme dikalangan Remaja di Gereja SidangSidang Jemaat Allah (GSJA) Wilayah Kabupaten Barito Timur Kalimantan Tengah.

c. Bagaimana peran aktif gereja dalam menangani praktik okultisme remaja di Gereja Sidang-Sidang Jemaat Allah (GSJA) Wilayah Kabupaten Barito Timur Kalimantan Tengah.

\subsection{Tujuan penelitian} adalah:

Adapun tujuan penelitian ini a. Untuk mengetahui praktik okultisme secara umum dalam kehidupan suku Dayak Maanyan.

b. Untuk mengetahui praktik okultisme dikalangan remaja di Gereja SidangSidang Jemaat Allah (GSJA) Wilayah Kabupaten Barito Timur Kalimantan Tengah.

c. Untuk mengetahui peran aktif gereja dalam menangani praktik okultisme pemuda remaja di Gereja SidangSidang Jemaat Allah (GSJA) Wilayah Kabupaten Barito Timur Kalimantan Tengah.

\subsection{Manfaat Penelitian}

Peneliti berharap hasil penelitian ini dapat memberikan banyak manfaat bagi masyarakat, yaitu:

\section{(a) Manfaat Teoritis}

Secara teoritis, penelitian ini diharap-kan dapat bermanfaat untuk dijadi-kan sebagai sumber informasi dalam menjawab permasalahan yang terjadi dalam kehidupan remaja yang ber-kaitan dengan praktik okultisme. Selain itu penelitian ini dapat bermanfaat sebagai bahan referensi dalam merancang proses pembelajaran Pendidikan Agama Kristen (PAK) di gereja dan sekolah; terutama dalam upaya mengatasi praktik okultisme di kalangan remaja. Peneliti juga berharap rancangan dalam penelitian ini yaitu: Deskripsi Praktik Okultisme di Kalangan Remaja di Gereja Sidang-Sidang Jemaat Allah (GSJA) Wilayah Kabupaten Barito Timur Kalimantan Tengah, dapat memberikan manfaat dalam meningkatkan kualitas pem-belajaran Pendidikan Agama Kristen (PAK) baik di lingkungan sekolah maupun gereja setempat. 
(b) Manfaat Praktis

Secara praktis penelitian ini diharap-kan dapat membeirkan manfaat yang signifikan bagi:

Bagi Pengajar, di mana manfaat pe-nelitian ini dapat mengembangkan kualitas pembelajaran Pendidikan Agama Kristen (PAK) menjadi lebih baik dan maksimal. Pengajar dapat menjalankan tugas sebagai pengajar dengan baik yaitu dengan merencanakan pembelajaran PAK secara matang baik di sekolah mau-pun gereja lokal serta mampu meng-identifikasi kesulitankesulitan belajar yang dialami oleh remaja ber-kaitan dengan praktik okultisme.

Bagi Para Remaja, manfaat peneliti-an ini bagi remaja yaitu dapat me-ningkatkan semangat dan motivasi dalam mengikuti pembelajaran Pendidikan Agama Kristen (PAK) baik di sekolah maupun gereja; karena telah terlebih dahulu dilakukan upaya pemberantasan atas praktik okultis-me yang terjadi di kalangan remaja. Dengan mengatasi praktik okultisme tersebut diharapkan dapat memberi-kan pengalaman belajar yang ber-makna dan tidak membuat naradidik jenuh. Selain itu kesulitan-kesulitan yang dialami oleh naradidik dalam memahami materi pembelajaran PAK dapat di atasi.

Bagi peneliti, manfaat penelitian ini bagi peneliti yaitu dapat memberikan pengalaman dalam melaksanakan proses pembelajaran Pendidikan Agama Kristen (PAK) dikalangan remaja dengan baik tanpa ada halangan karena praktik okultisme dapat di atasi. Selain itu penelitian ini juga dapat menjadi bahan informasi dan pengalaman dalam penyusunan desain kurikulum pembelajaran Pen-didikan Agama Kristen (PAK) baik di sekolah maupun gereja.
Bagi peneliti selanjutnya, manfaat dari penelitian ini dapat menjadi rujukan, sumber informasi dan bahan referensi penelitian selanjutnya agar bisa lebih dikembangkan dalam materi-materi yang lainnya untuk meningkatkan kualitas pembelajaran Pendidikan Agama Kristen (PAK). Selain itu peneliti juga berharap agar penelitian ini dapat memberikan motivasi kepada peneliti lain agar dapat lebih baik dalam merancang desain pembelajaran Pendidikan Agama Kristen (PAK).

\subsection{Sistematika Penulisan}

Untuk memberikan gambaran yang lebih jelas dan terarah, maka peneliti mengemukakan sistematika penulisan penelitian ini adalah sebagai berikut:

Bab Pertama, berisi penjelasan tentang latar belakang masalah, identifikasi masalah, batasan masalah, rumusan masalah, tujuan penelitian, manfaat penelitian, dan sistematika penulisan.

Bab Kedua, berisi landasan teori. Dalam bagian ini dibagi menjadi empat bagian, yaitu: Pertama membahas tentang Suku Dayak, yang meliputi asalusul dan penyebarannya serta rumpun dan sub suku yang di dalamnya terdapat Suku Dayak Maanyan, serta kepercayaan setempat. Kedua membicarakan sejarah Pekabaran Injil di Kalimantan, khususnya di wilayah Kalimantan Tengah dan Kalimantan Selatan yang merupakan wilayah dominasi Suku Dayak Maayan. Ketiga membahas tentang pengertian Okultisme dan halhal praktik Okultisme dalam kehidupan orang percaya, khususnya pada suku Dayak Maanyan. Keempat membahas tentang remaja dan hal-hal yang berkaitan dengan kelompok ini.

Bagian Ketiga memuat metode penelitian: penelitian kualitatif, teknik pengumpulan data, instrumen penelitian, 
populasi dan sampel, teknik analisis data.

Bagian Keempat berisi tentang hasil penelitian mengenai Deskripsi Praktik Okultisme di Kalangan Remaja Suku Dayak Maanyan di Gereja SidangSidang Jemaat Allah (GSJA) Wilayah Kabupaten Barito Timur Kalimantan Tengah.

Bagian Kelima berisi saran dan kesimpulan atas pembahasan yang dikaji yaitu: Deskripsi Praktik Okultisme di Kalangan Remaja Suku Dayak Maanyan di Gereja Sidang-Sidang Jemaat Allah (GSJA) Wilayah Kabupaten Barito Timur Kalimantan Tengah.

\section{Kajian Teori}

Kelompok masyarakat yang mendiami pulau besar Kalimantan adalah: Dayak, Melayu, Banjar, Kutai dan Paser. Namun dari kelima kelompok masyarakat yang disebutkan tersebut, suku Dayak-lah yang paling menonjol karena dianggap mendominasi pulau tersebut. Istilah Dayak berhubungan dengan hulu atau sungai, dan orangorang yang tinggal di kawasan itu kemudian dipanggil sebagai orang Dayak.

Istilah Dayak pada yang mulanya bukan sekedar untuk menunjuk kelompok masyarakat yang tinggal di tepi sungai dan pedalaman; namun juga untuk mem-bedakan dengan masyarakat pesisir yang pada umumnya memeluk agama Islam. Jadi pada dasarnya kata Dayak tidak me-nunjuk kepada nama kelompok etnis atau suku bangsa, namun lebih menekankan pada aspek sosioreligiusnya. Masyarakat pedalaman Kalimantan itu sendiri lebih suka di sebut dengan orang Daya. Kata ini mungkin berasal dari bahasa Iban yang berarti manusia. Ada juga yang mengartikannya sebagai pedalaman atau hulu. ${ }^{7}$ Dalam beberapa literatur, istilah Daya, Dyak, Daya dan Dayak menunjuk kepada masyarakat yang tinggal di pedalaman Kalimantan, dan kata Dayak-lah yang paling umum dipergunakan.

Mikhail Coomans menyatakan bahwa penduduk Kalimantan Tengah dapat dikelompokkan kepada dua kelompok besar, yaitu Halo dan Dayak. Nama Halo adalah sebutan dari bahasa Dayak untuk orang Dayak yang beragama Islam. Karena itu pengistilahan Halo dan Dayak adalah istilah Sosio-Religius bukan istilah antropologis yang membedakan sukusuku bangsa. ${ }^{8}$ Walau-pun sebagian besar masyarakat Dayak memeluk agama Kristen, namun sekitar $10 \%$ diantaranya masih teguh dengan keyakinan Kaharingan. Hingga kini, keyakinan tersebut terpelihara dengan baik, dan bahkan masuk dalam program pembinaan spiritual dari pemerintah setempat.

Rumpun Suku Dayak yang mendiami wilayah Kalimantan Tengah terdiri atas Dayak Hulu dan Dayak Hilir. Suku Dayak Hulu terdiri atas: Dayak Ot Danum, Dayak Siang, Dayak Murung, Dayak Taboyan, Dayak Lawangan, Dayak Dusun dan Dayak Maanyan. Selanjutnya Suku Dayak Hilir, yang merupakan Rumpun Ngaju, terdiri atas: Dayak Ngaju, Dayak Bakumpai, Dayak Katingan, dan Dayak Sampit. Suku Dayak Ngaju merupakan kelompok yang

\footnotetext{
${ }^{7}$ Zulyani Hidayah, Ensiklopedia Suku Bangsa-bangsa di Indonesia, (Jakarta.Yayasan Pustaka Obor Indonesia.2015), h. 111.

${ }^{8}$ Mikhail Coomans, Manusia Daya: Dahulu, Sekarang, Masa Depan, (Jakarta: Gramedia 1987); diakses 26 April 2018 pukul 10.40 WIB,

https://koekoeh.wordpress.com/2012/04/30/meng enal-suku-bangsa-dayak/
} 
paling dominan di Kalimantan Tengah.

Salah satu rumpun dari Suku Dayak adalah, Suku Dayak Maanyan yang juga dikenal sebagai suku Dayak Barito Timur; yang mendiami wilayah Kalimantan Tengah Bagian Selatan, yaitu Barito Timur dan Barito Selatan. Sebagi-an orang Dayak Maanyan juga mendiami wilayah Kalimantan Selatan, sebab me-nurut tradisi yang diceritakan secara turun-temurun menyatakan bahwa pe-mukiman pertama suku Dayak Maanyan adalah di tepi sungai Martapura, Kayu Tangi, Marampiau, Tane Karang Anyan serta di sepanjang sungai Tabalong Serta menyusuri sungai Barito yakni sunagi-sungai Sirau, disekitar Patai dan aliran sungai lainnya. Suku Dayak Ma'anyan masih terbagi dalam beberapa sub-etnis, di antaranya: Maanyan Paku, Maanyan Patai, Maanyan Paju epat, Maanyan Dayu, Maanyan Paju Sapuluh, Maanyan Jangkung, Maanyan Banua Lima dan Maanyan Warukin.

Suku Dayak yang mendiami wilayah Kalimantan Tengah Bagian Selatan pernah membangun suatu kerajaan yang dikenal dengan nama Kerajaan Dayak Nansarunai, yang kemudian mereka kalah dalam peperangan dengan Kerajaan Majapahit yang pecah ketika Prabu Hayam Wuruk mengirim ekspedisi militer pertama pada tahun 1356 dan me-nyerang Kalimantan Bagian Selatan. Pangliman perang Kerajaan Majapahit, Empu Jatmika ditugaskan untuk menaklukkan Kerajaan Dayak Nansarunai atau yang dikenal juga sebagai Kerajaan Dayak Maanyan. Fridolin Ukur mengata-kan bahwa atas perintah Hayam Wuruk, pasukan Majapahit pimpinan Empu Jatmika menyerang Nansarunai hingga takluk. Oleh para seniman lokal, tragedi runtuhnya Nansarunai ini diungkapkan dalam puisi ratapan atau wadian dalam bahasa Maanyan yang disebut peristiwa Usak Jawa atau Penyerangan oleh Kerajaan Jawa. ${ }^{9}$ Keruntuhan Kerajaan Nansarunai sekaligus membuat masyarakat Dayak Maanyan untuk masuk lebih jauh lagi ke wilayah pedalaman. Itulah sebabnya kawasan pesisir daerah Kalimantan Selatan banyak dodominasi oleh suku Banjar yang mayoritas me-meluk agama Islam.

\subsection{Kepercayaan Masyarakat Dayak Maanyan}

Kepercayaan mula-mula Suku Dayak Maanyan adalah Kaharingan, dan kpercayaan ini merupakan kepercayaan yang umum dalam kehidupan semua masyarakat Dayak. Keyakinan lokal masyarakat Dayak menyatakan bahwa suku ini berasal dari Panaturan Tetek Tatum; yang diyakini sebagai orang pertama yang menempati bumi atau menginjakan kakinya di Kalimantan, yaitu Raja Bunu. ${ }^{10}$ Agama Kaharingan adalah ke-percayaan turun-temurun yang diwaris-kan oleh nenek moyang. Sepertinya agama ini tidak terlepas dari keseharian masyarakat Suku Dayak yang sangat dekat dengan alam sehingga apa yang menjadi ritual mereka tidak terlepas dengan keadaan lingkungan mereka. Sebenarnya tidak semua orang menama-kan kepercayaan mereka itu Kaharingan. Mereka sendiri lazim menyebutnya agama helu atau agama zaman dulu dan kadang-kadang juga agama biasa. ${ }^{11}$

\footnotetext{
${ }^{9}$ Fridolin Ukur, Tanya Jawab tentang
} Suku Dayak. (Jakarta: BPK Gunung Mulia, 1977), h. 46.

${ }^{10}$ https://id.wikipedia.org/wiki/Kalimanta n_Tengah, diakses hari Senin, 2 Juli 2018, Pkl. 11.35 WIB.

${ }^{11}$ Sarwoto Kertodipoero, Kaharingan, Religi dan Penghidupan di Pehuluan 
Agama Kaharingan merupakan kepercayaan asli suku Dayak. Sebutan Kaharingan diambil dari kata Danum Kaharingan, yang berarti air kehidupan. ${ }^{12}$ Istilah Kaharingan berasal dari bahasa Sangen, yaitu bahasa Dayak kuno, yang berasal dari kata Haring yang berarti ada dan tumbuh atau hidup, dilambangkan dengan Batang Garing atau Pohon Kehidupan. Pohon ini berbentuk seperti tombak dan menunjuk tegak ke atas. Bagian bawah pohon terdapat guci berisi air suci yang melambangkan Jata atau dunia bawah. Antara pohon sebagai dunia atas dan guci sebagai dunia bawah merupakan dua dunia yang berbeda tapi diikat oleh satu kesatuan yang saling ber-hubungan dan saling membutuhkan. Tempat bertumpu Batang Garing adalah Pulau Bantu Nindan Tarung yaitu pulau tempat kediaman manusia pertama sebelum manusia diturunkan ke bumi. Dengan demikian orang-orang Dayak diingatkan bahwa dunia ini adalah tempat tinggal sementara bagi manusia, karena tanah air manusia yang sebenarnya adalah di dunia atas yaitu di Lawu Tatau. ${ }^{13}$

Pada masa pemerintahan Orde Baru, para penganut agama Kaharingan ber-integrasi dengan agama Hindu, sehingga menjadi agama Hindu Kaharingan. $^{14}$ Itulah sebabnya pemerintah Indonesia kala itu mewajibkan penduduk dan warga

Kalimantan, (Bandung: Penerbitan Sumur, 1963), h. 13.

${ }^{12}$ Ibid, h. 16.
${ }^{13}$ Mirwaty, Budaya yang Tersembunyi di Indonesia, diakses pada tanggal 7 Maret 2018 pkl 15.25 WIB dari http://mirwaty.blogspot.co.id/ 2013/05/budaya-yang-tersembunyi di indonesia_11.html

${ }^{14}$ http://www.academia.edu/9006623/Mak alah_Agama_Kaharingan, diunduh pada tanggal 4 Juni 2018, pukul 11.00 WIB. negaranya untuk menganut salah satu agama yang diakui oleh Pemerintah Republik Indonesia. Jadi kepercayaan Kaharingan yang telah dikategorikan sebagai agama Hindu resmi tercatat pada tanggal 20 April 1980. ${ }^{15}$

Dalam keyakinan masyarakat Dayak Maanyan, beberapa istilah yang hingga kini dikenal baik di antaranya adalah: Wadian atau Balian yaitu orang yang menjadi pemimpin ritual dalam beberapa upacara adat Dayak. Damang atau Damung adalah pemimpin atau tokoh masyarakat adat Dayak Maanyan. Mantir adalah tetua adat atau kepala suku atau kepala adat yang dihormati di tengah masyarakat Dayak Maanyan. Wadian Matei adalah pemimpin ritual dalam upacara kematian suku Dayak Maanyan. Wadian Welum adalah pemimpin ritual dalam upacara pengucapan syukur. Datu Tunyung adalah surga dalam kepercayaan suku Dayak Maanyan. Talamana Tuah Hukat adalah Tuhan dalam kepercayaan suku Dayak Maanyan dan juga sering disebut Alatala. Kariau adalah roh-roh atau makhluk halus. Adiau adalah roh orang yang sudah meninggal. Orang Dayak Maanyan masih setia menjalankan tradisi adat, dan bahkan pemerintah setempat menjadikannya sebagai sarana promosi untuk bidang kepariwisata. Dengan adanya dukungan pemerintah yang melembaga hingga sampai ke masyarakat, maka tradisi dan keyakinan ini tetap terjaga.

Keyakinan masyarakat suku Dayak Maanyan yang menghubungkannya dengan roh-roh leluhur dan bahkan rohroh lainnya serta ritual yang tidak lazim dalam kekristenan; dianggap membahayakan kehidupan umat Kristen sebab adanya pertentangan keyakinan 
yang cukup signifikan di antara keduanya. Orang Dayak yang masih memeluk agama Kaharingan tentunya tidak terbebani dengan pelaksanaan berbagai upacara adat dan keagamaan ini, namun bagi masyarakat Dayak Maanyan yang telah memeluk agama Kristen, hal tersebut menjadi sebuah pertentangan iman tersendiri sebab kekristenan sangat jelas melarang upacara-upacara keagamaan yang dihubungkan dengan penyembahan terhadap roh-roh nenek moyang, ataupun kekuatan-kekuatan gaib lainnya, selain Tuhan Allah itu sendiri.

Ada banyak aspek dalam kehidupan masyarakat Dayak Maanyan yang selalu dihubungkan dengan penyembahan leluhur dan kepada rohroh orang yang sudah mati. Pada dasarnya, hukum adat Dayak Maanyan terbagi atas tiga wilayah hukum adat yaitu wilayah Banua Lima, Paju Empat dan Paju Sepuluh, dan masing-masing memiliki bentuk upacara adat yang beragam.

Bagi orang Ma'anyan yang hendak memasuki jenjang pernikahan, maka Natas Banyang dipakai dalam acara pernikahan. Natas Banyang yang dimulai sejak masa kerajaan Nansarunai, me-miliki pengertian aman, tentram dan damai sejahtera; yang merupakan sebuah upacara adat yang bermakna nazar dari orang tua yang menikahkan anaknya, dan menjadi sebuah kesepakatan kedua keluarga besar yang kini terikat. Kepercayaan lainnya adalah Itaruk Kasai atau Tampung Tawar yang sering dipakai dalam acara Ngumpe Sawuh, yaitu mem-buang penyakit. Upacara ini dilakukan dengan cara memerciki anak yang baru lahir menggunakan air, dengan tujuan membuang penyakit yang ada dalam diri-nya, dan air itu juga sekaligus sebagai lambang bahwa ia telah menjadi warga baru dan diterima di dalam masyarakat itu. Kepercayaan masyarakat Dayak Maanyan yang paling populer dan seringkali dilakukan secara besar-besaran adalah upacara kematian. Dari semua upacara adat yang diselenggarakan masyarakat Dayak Ma'anyan, selalu dihubungkan dengan kepercayaan Kaharingan yang memang dekat dengan penyembahan terhadap leluhur dan ke-percayaan terhadap rohroh dan benda-benda gaib lainnya.

Upacara Ipaket adalah ritual adat yang diselenggarakan oleh masyarakat adat Dayak Maanyan sebagai bentuk pengucapan syukur atas hasil bumi yang mereka peroleh. Upacara ini bertujuan untuk memohon perlindungan spiritual bagi masyarakat desa, dan dilaksanakan pada setiap tahun. Masyarakat Dayak Ma'anyan percaya bahwa dengan melaksanakan Ipaket maka mereka akan terlindungi dari berbagai marabahaya.

Upacara Kematian. Kepercayaan kuno orang Dayak Maanyan dalam Upacara Adat Kematian. Masyarakat Dayak Maanyan percaya bahwa kematian adalah sebuah awal perpindahan atau perjalanan roh (adiau atau amirue) ke kemuliaan dunia baru (tumpuk adiau) yang subur, damai, tentram, kaya raya di mana di sana ada kesempurnaan. Itulah sebabnya ada upacara khusus bagi mereka yang meninggal dunia.

Upacara kematian yang lengkap dalam tradisi Suku Dayak Maanyan disebut Marabia, Ijambe dan Ngadatonuntuk. Upacara ini harus dilaksanakan secara lengkap menurut adat agar sampai ke Datu Tunyung atau sorga; dan jika tidak dilakukan secara lengkap, maka arwah atau adiau bisa gentayangan, dan hal inilah yang ditakuti oleh mereka yang masih hidup. Dalam serangkaian upacara kematian yang 
dimaksud, Balian atau Wadian Matei berperan memanggil, mengantar dan menunjuk jalan yang ber-liku-liku agar sampai ke Datu Tunyung yang dikatakan penuh dengan keriaan, kecukupan tak berhingga. Pelaksanaan upacara kematian kematian yang di-maksud, dilaksanakan mulai dari satu malam, dua, tiga, lima, tujuh dan bahkan sembilan; dengan urutan hari pelaksanaannya adalah: Tarawen, Irupak, Irapat, Nantak Siukur dalam Marabia, untuk Ngadatonuntuk dan Ijambe.

Dalam konteks iman Kristen, diduga praktek Okultisme dalam upacara ke-agamaan yang dilakukan, khususnya pada upacara kematian sangat kental. Jika hal itu dilakukan oleh pemeluk agama Kaharingan tentunya tidak menjadi masalah. Namun demikian, masyarakat Dayak Maanyan yang sudah beragama Kristen diduga melaksanakannya sebagai bagian dari kehidupan keseharian. Jadi peran gereja inilah yang harus lebih di-tingkatkan dalam upaya pembinaan iman jemaat.

\subsection{Sejarah Pekabaran Injil di Kalimantan}

Sejarah Pekabaran Injil di pulau Kalimantan mulai dilakukan pada tahun 1830, namun demikian pelayanan misionari Katolik sudah dilakukan jauhjauh hari sebelumnya. Misionaris Kristen dari organisasi Rheinische Missionsgezelschaft zu Barmen (RMG) adalah J. H. Barnstein dan Heyer yang di-utus ke Kalimantan, namun hanya Barnstein yang bisa sampai sebab Heyer harus kembali ke Jerman karena sakit. Pada tanggal 26 Juni 1835, Barnstein untuk pertama kalinya menginjakkan kakinya di Banjarmasin, dan enam bulan kemudian datang lagi Becker, Hupperts dan Krusmann, misionaris dari Jerman, dan terus lagi berdatangan tenaga pelayanan lainnya. Salah satu keberhasilan Barnstein dalam mengabarkan Injil adalah dengan mengikuti upacara Hangkat hampahari hatunding daha atau angkat saudara dengan pertukaran darah dengan Temanggung Ambo Nikodemus, Kepala Suku setempat. Karena Barnstein telah dianggap sebagai saudara maka upaya pekabaran Injil di pulau ini terus berlangsung dengan baik.

Setelah J. H. Barnstien berkarya dan meninggal dunia, pekerjaan Pekabaran Injil di Kalimantan diteruskan oleh Clasisschale Zending yaitu organisasi Zending Belanda. Itulah sebabnya ter-dapat sejumlah nama misionaris yang ter-libat dan bahkan berdirilah sejumlah gereja lokal di sana. Tercatat pada tahun 1839-1840 yang dipandang sebagai tahap pertama dari usaha Pekabaran Injil di wilayah Betabara, dilayani Miss Berger; sementara di Palingkau Misionaris Backer. Selanjutnya pada tahun 1841 dibuka pos pelayanan Pekabaran Injil baru di desa Gohong dan di Bontoi atau Penda Alai. Pada tahap berikutnya, yaitu tahap ketiga pada tahun 1851 di Dusun Timur, tepatnya di Morotuwu, yaitu sepanjang Sungai Barito, dilayani oleh L.E. Denninger. Tahap keempat, berpusat di Pulau Telo di Tanggohan dan di Pangkoh yang dilayani E.E Hoffmesiter pada tahun 1855, dan akhirnya pada tahun 1857 tahap kelima, di Tamiang Layang oleh Missionaris J.C Klammer; dan ditempat inilah peneliti tinggal dan melakukan penelitian ini.

Pada masa sekarang ini, kekristenan di suku Dayak, khususnya Dayak Maanyan mengalami perkembangan yang sangat baik. Tercatat sejumlah gereja lama, seperti GKE (Gereja Kalimantan Evangelis) 
yang berdiri sejak tahun 1925, GPIB (Gereja Protestan di Indonesia bagian Barat). Kelompok gereja-gereja Injili, seperti GKNI (Gereja Kristen Nasional Indonesia), dan GKRI (Gereja Kristus Rahmani Indonesia) juga turut serta dan gereja-gereja beraliran Karismatik juga tidak ketinggalan, seperti: GBI (Gereja Bethel Indonesia), GPdI (Gereja Pantekosta di Indonesia) dan GSJA (Gereja Sidang Sidang Jemaat Allah) telah ikut serta memberitakan Injil pada masyarakat Dayak Maanyan. Tentunya masih banyak gereja lokal lain-nya yang belum sempat terdata.

\subsection{Okultisme dan Praktik Okultisme}

Salah satu pokok bahasa yang populer dalam masyarakat Kristen adalah okultisme, dan istilah okultisme diduga untuk pertama kalinya diperkenalkan oleh seorang berkebangsaan Perancis yang bernama Eliphas Levi dengan istilah occultisme pada tahun1810-1875 dan seorang Inggris yang bernama A. P. Sinnet pada tahun 1881 dengan istilah occultism. ${ }^{16}$ Kala itu masyarakat Eropa yang banyak dipengaruhi oleh rasionalis-me dan ilmu pengetahuan. Pada waktu pertama kali diperkenalkan, istilah Okultisme menunjuk kepada suatu bidang keilmuan dan seni, yang me-nunjuk kepada bidang kajian Esosentris-me, yaitu semacam ilmu kebatinan. Kemudian istilah ini berkembang ke arah yang lebih ekstrim, yaitu kuasa ke-gelapan.

Kini istilah okultisme dipahami sebagai kepercayaan pada hal-hal yang supranatural Soejono dalam Kamus Sosiologi menyatakan bahwa okultisme adalah kepercayaan kepada kekuatan gaib yang dapat dikuasai manusia atau

${ }^{16}$ Christopher I. Lerich, The Occult Mind, (Newyork: Cornel University, 2007), p. 3. kajian kekuatan gaib. ${ }^{17}$ okultisme berasal dari istilah "ocult" artinya gelap, misterius, tersembunyi dan "isme" adalah ajaran, jadi dapat dikatakan bahwa okultisme adalah pengetahuan atau ajaran, paham, doktrin tentang halhal yang sifatnya rahasia, gelap, misterius dan tersembunyi, khususnya menyangkut kuasa kegelap-an. ${ }^{18} \mathrm{H}$. Soekahar menambahkan bahwa okultisme sebenarnya berasal dari kata Latin occultus, artinya: tersembunyi, rahasia, sial, celaka, gaib, gelap, dan misterius. Jadi okultisme berarti penglibatan diri dengan kuasa, kegelapan, gaib, agar mengalami hal-hal yang rahasia aneh, dan misterius." 19 Pendapat Soekahar di atas, didukung oleh Lardie Debra, dalam buku yang berjudul: Concise Dictionary of the Occult and New Age, yang berpendapat bahwa okultisme dipahami sebagai sebuah ke-percayaan terhadap keberadaan pe-ngetahuan yang rahasia dan kekuatan supernormal yang memungkinkan semua itu berada di bawah kendali manusia. ${ }^{20}$ Dengan memperhatikan pola kehidupan masyarakat Timur yang memang memberi tempat bagi praktik okultisme, maka Kurt Koch menyatakan bahwa:

Okultisme adalah paham atau kepercayaan terhadap alam supranatural, misterius, gaib, dengan ber-bagai sosok gaib dan misterius,

${ }^{17}$ Soejono Soekanto, Kamus Sosiologi, (Jakarta: CV. Rajawali, 1983), h. 343.

${ }^{18}$ E.P. Gintings, Iblis dan Okultisme, (Kabanjahe: GBKP, Abdi Karya, 2000), h. 3.

${ }^{19}$ H. Soekahar, Satanisme dalam Pelayanan Pastoral, (Malang: Gandum Mas, 1983), h. 6

${ }^{20}$ Lardie Debra, Concise Dictionary of The Occult and New Age, (Grand Rapids: Kregel Publication, 1999). p. 418 
yang diikuti oleh berbagai ritual atau ritus dengan tujuan tertentu. ${ }^{21}$

Kepercayaan kepada para leluhur dan roh-roh serta benda-benda gaib dan bahkan keyakinan akan suatu kekuatan gaib, termasuk dalam keyakinan okultisme. Sebagai contohnya adalah hal kematian dalam keyakinan suku Dayak, sebagaimana diungkapkan oleh Harun Hadiwijono bahwa:

Bagi orang Dayak, orang yang mati diadakan dua macam penguburan, yaitu upacara kematian biasa (ritus penguburan) dan pesta kematian yang disebut tiwah. Upacara kematian dimaksudkan untuk memimpin liau ke tempat peristirahatan sementara, yaitu Bukit Pasahan Raung. Para liau menunggu hingga diadakan upacara kedua yaitu upacara tiwah. Upacara tiwah ini tidak boleh diabaikan, karena apabila diabaikan akan mendatangkan bencana kepada keluarga yang masih hidup. Upacara ini merupakan upacara pemakanan terakhir yaitu dengan memakamkan tulang-tulang sang wafat di tempat peristirahatan tetap yang disebut sandong. ${ }^{22}$

Keyakinan masyarakat Dayak Maanyan telah menjadi bagian hidup yang tak ter-pisahkan, namun sebagai orang yang sudah percaya kepada Kristus; diperlukan sikap yang bijak dalam menjalani tradisi atau adat istiadat. Perlunya sikap tegas untuk tidak terlibat dalam prakteik-praktik okultisme yang memang nyata dalam setiap kegiatan peribadatan dan upacara keagamaan setempat.

${ }^{21}$ Kurt Koch , Occult ABC, (Michigan:

Grand Rapids, 1978), p. 207

${ }^{22}$ Harun Hadiwijono, Religi Suku Murba di Indonesia, (Jakarta: Gunung Mulia, 2003), h.66.

\subsection{Remaja}

Istilah remaja berasal dari bahasa Latin yaitu adolescere yang berarti to grow atau to grow maturity, yang artinya tumbuh atau tumbuh menjadi dewasa. Istilah adolescence seperti yang dipergunakan saat ini, mempunyai arti yang lebih luas, mencakup kematangan mental, emosional, sosial dan fisik. ${ }^{23}$ Remaja adalah masa peralihan yang ditempuh oleh seseorang dari kanakkanak menuju dewasa atau dapat dikatakan bahwa masa remaja adalah perpanjangan masa kanak-kanak sebelum mencapai masa dewasa. ${ }^{24}$ Selain sebagai bagian dari peralihan masa kehidupan seseorang; remaja juga menunjuk kepada salah satu satu tahapan perkembangan manusia dengan ciri manusia tersebut sering mengalami masa krisis identitas dan ambigu. Hal yang demikian menyebabkan remaja menjadi tidak stabil, agresif, konflik antara sikap dan perilaku, kegoyahan emosional dan sensitif, terlalu cepat dan gegabah untuk mengambil tindakan yang ekstrim. Dari sifat remaja yang mudah mengalami kegoyahan emosional dan gegabah tersebut menyebabkan remaja tidak mudah untuk mempertahankan emosinya yang positif sehingga se-bagian besar individu yang masuk pada tahap perkembangan remaja sering menunjukkan perilaku agresif baik kepada teman, orang tua maupun kepada orang lain yang lebih muda. ${ }^{25}$

\section{${ }^{23}$ Elizabeth.B.Hurlock, Psikologi}

Perkembangan Suatu Pendekatan Sepanjang Rentang Kehidupan, (Jakarta: Erlangga, 2002), h. 206.

${ }^{24}$ Zakiyah Daradjat, Membina Nilai-nilai Moral di Indonesia, (Jakarta: Bulan Bintang, 1976), h. 69.

25 John W. Santrock, John W. Perkembangan Anak, (Jakarta: Erlangga, 2011), h. 67 
Elizabeth B. Hurlock, dalam buku Psikologi Perkembangan memberikan penggolongan remaja dalam tiga tahap, yaitu:

Masa Pra-Remaja, yaitu usia 12-14 tahun, di mana periode sekitar kurang lebih dua tahun sebelum terjadinya pemasakan seksual yang sesungguhnya tetapi sudah terjadi perkembangan fisiologi yang berhubungan dengan pemasakan beberapa kelenjar endokrin. Masa Remaja Awal, yaitu pada usia 1417 tahun, di mana periode dalam rentang perkembangan terjadi kematangan alatalat seksual dan tercapai kemampuan reproduksi, dan terakhir adalah Masa Remaja Akhir, yaitu pada usia 17-21 tahun, di mana seseorang tumbuh menjadi dewasa yang mencakup kematangan mental, emosional, sosial dan fisik. ${ }^{26}$ Selanjutnya tahap perkembangan remaja dapat terlihat sebagaimana uraian berikut ini, yaitu:

Konsep diri berubah sesuai dengan perkembangan biologis; Mencoba nilainilai yang berlaku; Pertambahan maksimal pada tinggi dan berat badan; Stress meningkat terutama saat terjadi konflik; Anak wanita mulai mendapatkan haid, tampak lebih gemuk; Berbicara lama di telepon, suasana hati berubah-ubah (emosi labil), serta kesukaan seksual mulai terlihat; Menyesuaikan diri dengan standar kelompok; Anak laki-laki lebih menyukai olahraga, anak perempuan suka bicara tentang pakaian atau make up; Hubungan anak dengan orang tua mencapai titik terendah, anak mulai melepaskan diri dari orang tua; Takut di tolak oleh teman sebayanya; Pada masa akhir remaja mencapai maturitas fisik, mengejar carier, identitas seksual

${ }^{26}$ Elizabeth B. Hurlock, Psikologi Perkembangan. h. 206. terbentuk, lebih nyaman dengan diri sendiri, kelompok sebaya kurang begitu penting, emosi lebih terkontrol, serta membentuk hubungan yang menetap. ${ }^{27}$

\section{Metodologi Penelitian}

\subsection{Jenis penelitian}

Peneliti menggunakan jenis peneliti-an kualitatif dengan pendekatan deskriptif, dalam melakukan penelitian ini. Sugiyono memberikan pengertian penelitian deskriptif sebagai salah satu metode kualitatif deskriptif dengan penelitian analisis data yang langsung diteliti berdasarkan data di lapangan dan menjabarkan data dengan menggunakan teks atau kata-kata dn bukan angkaangka. $^{28}$ Dan Nazir menambahkannya dengan menyatakan bahwa metode deskriptif adalah suatu metode dalam meneliti status sekelompok manusia, suatu obyek, suatu set kondisi, suatu sistem pemikiran atau peristiwa pemikiran masa senang. ${ }^{29}$ Jadi hasil penelitian yang dijabarkan dengan katakata itu bersifat deskripsi.

Penelitian kualitatif antara lain dilakukan secara alamiah karena langsung ke sumber data dan peneliti sebagai instrumen penting. Peneliti cenderung idealis dan menekankan subjektifitas tetapi tidak memaksakan agar orang lain memiliki pandangan yang sama. $^{30}$ Itulah sebabnya peneliti berupaya supaya dapat menerima pendapat yang berbeda dengan apa yang

${ }^{27}$ Abdul Nasir dan Abdul Muhith, Dasar-

Dasar Keperawatan Jiwa Pengantar dan Teori.

(Jakarta: Salemba Medika, 2011), h. 124.

${ }^{28}$ Sugiyono, Metode Penelitian

Manajemen, (Bandung: Alfabetta, 2016), h. 13.

${ }^{29}$ Muhammad Nazir, Metode penelitian,

(Jakarta: Ghalia Indonesia, 1998), h. 63.

${ }^{30}$ Lexy J. Moleong, Metodologi

Penelitian Kualitatif, (Bandung: Remaja

Rosdakarya, 2012), h. 14. 
diyakini; tentunya hal tersebut menjadi bahan pembanding dalam me-lakukan suatu penelitian.

Metode kualitatif deskriptif diguna-kan peneliti untuk mencapai suatu pandangan dan jawaban mengenai segala sesuatu yang berhubungan dengan "Deskripsi Praktik Okultisme di Kalangan Remaja Suku Dayak Ma'anyan di Gereja-Gereja Sidang Jemaat Allah (GSJA) Wilayah Kabupaten Barito Timur Kalimantan Tengah" Metode penelitian ini dilakukan agar peneliti mengetahui praktik Okultisme di kalangan remaja gereja, sehingga dalam pengumpulan data peneliti dapat melihat secara langsung melalui penelitian yang dilakukan.

\subsection{Tempat dan Waktu Penelitian}

Penelitian ini dilakukan di kalangan remaja suka Dayak Maanyan di Gereja Sidang-Sidang Jemaat Allah (GSJA) di Kabupaten Barito Timur Kalimantan Tengah. Pelaksanaan penelitian pada September 2017-Juli 2018, dalam beberapa kali perkunjungan lapangan.

\subsection{Mekanisme dan Rancangan Penelitian}

Penelitian dimulai setelah mendapat informasi dari observasi atas hal-hal yang dibutuhkan, seperti apakah remaja suku Dayak Ma'anyan terlibat dalam praktik Okultisme. Kemudian mengobservasi hal-hal yang diduga sebagai praktik Okultisme dikalangan remaja di Gereja Sidang-Sidang Jemaat Allah di wilayah Kabupaten Barito Timur Kalimantan Tengah. Untuk membuktikan adanya praktik okultisme di kalangan remaja, dan perlunya jalan keluar atas apa yang telah terjadi. Dalam penelitian ini, peneliti sendiri yang menempatkan diri sebagai participant observer. Dalam metode penelitian kualitatif, penelitilah yang mengkonstruksi dunia melalui refleksinya sebagai mahluk sosial, politik dan budaya. $^{31}$ Hal ini menunjukkan bahwa peneliti yang merupakan kunci instrumen karena dapat merasakan dan melihat sendiri objek atau subjek yang sedang diteliti.

\subsubsection{Populasi dan Sampel}

Sampel adalah bagian dari jumlah data karakteristik yang dimiliki oleh populasi. Dalam penelitian kualitatif, sampel sumber data dipilih secara purpsive. ${ }^{32}$ Purposive sampling adalah teknik pengambilan sampel sumber data dengan pertimbangan tertentu. Pertimbangan tertentu ini, misalnya orang tersebut yang dianggap paling tahu tentan apa yang diharapkan, atau barangkali ia sebagai penguasa, sehingga akan mem-permuda peneliti menjelajahi objek dalam situasi sosial yang diteliti. Sampel yang menjadi sumber data atau sebagai informan sebaiknya memiliki kriteria yang menjadi syarat penelitian kualitatif. Di mana informan yang menjadi sampel data memiliki andil dalam praktik Okultisme.

Selanjutnya peneliti mengambil sampel informan sebanyak 42 orang yang terdiri dari 10 orang Pendeta, 17 orang Remaja dan 15 Orang Tua; sebagai informan penelitian tentang Deskripsi Praktik Okultisme di Kalangan Remaja di Gereja Sidang-Sidang Jemaat Allah (GSJA) di Wilayah Kabupaten Barito Timur Kalimantan Tengah.

31 J. R. Raco, Metode Penelitian Kualitatif (Jakarta: Grasindo, 2010), h. 12.

32 Sugiyono, Metode Penelitian Pendidikan, Pendekatan Kuantitatif, kualitatif dan R\&D, (Bandung: Alfabeta, 2016), h. 85. 


\subsubsection{Teknik Pengumpulan Data}

Teknik pengumpulan data adalah langkah yang penting karena tujuan utama penelitian ini adalah untuk mendapatkan data. Secara umum terdapat empat macam teknik pengumpulan data yaitu: Observasi, Wawancara, Dokumentasi dan Gabungan atas ketiga-nya, yaitu Triangulasi. Pada penelitian inipengumpulan data yang dilakukan antara lain:

Wawancara, adalah teknik pengumpulan data yang dipergunakan dalam penelitian ini. Teknik pengumpulan data ini berdasarkan pada laporan tentang diri sendiri atau setidaknya pada pengetahuan atau keyakinan pribadi. Sutrisno Hadi dalam Sugiyono menyatakan bahwa ada beberapa syarat apabila menggunakan metode wawancara, yaitu: Subjek adalah orang yang paling tahu tentang dirinya. Apa yang dinyatakan subjek kepada peneliti adalah benar dan dapat di percaya, dan Interpretasi subjek terhadap pertanyaan peneliti sama dengan apa yang diharapkan peneliti. ${ }^{33}$

Salah satu metode pengumpulan data ialah dengan jalan wawancara. Wawan-cara ialah merupakan suatu interaksi dan komunikasi. ${ }^{34}$ Tujuannya adalah untuk mengumpulkan informasi dengan cara bertanya langsung kepada responden. Selain itu sumber informasi yang lain adalah dari dokumen tertulis seperti sumber buku, majalah ilmiah, arsip, dokumen pribadi dan dokumen resmi merupakan sumber tambahan. ${ }^{35}$

${ }^{33}$ Sugiyono, Metode Penelitian

Pendidikan, Pendekatan Kuantitatif, kualitatif dan $R \& D$, (Bandung: Alfabeta, 2016), h. 194.

${ }^{34}$ Masri Singarimbun \& Sofian Effendi (Ed), Metode Penelitian Survai (Jakarta: LP3LS, 1989), 192.

${ }^{35}$ Lexy J. Moleong, Metodologi

Penelitian ..., 112-113.
Sumber data tambahan ini sangat penting untuk mendukung sumber utama dalam pe-nelitian wajib dilampirkan hasilnya dan data asli. Sumber data tambahan ini sangat penting untuk mendukung sumber utama dalam penelitian wajib dilampirkan hasilnya dan data asli.

Wawancara adalah teknik pengumpulan data yang dilakukan dengan tanya jawab sepihak, dan yang dilakukan antara secara sistematis dan berlandaskan tujuan penelitian. Wawancara dilakukan antara dua pihak yaitu pewawancara atau orang yang melakukan wawancara dengan mengajukan pertanyaan dan orang yang diwawancarai yaitu mereka yang menjawab pertanyaan yang diajukan. ${ }^{36}$

Literatur diartikan sebagai sumber atau acuan yang digunakan dalam berbagai aktivitas dalam dunia pendidikan ataupun lainnya. Literatur dapat juga disebutkan sebagai rujukan yang dimanfaatkan untuk informasi secara intelektual. Studi literatur atau studi pustaka adalah tehnik pengumpulan data dengan cara memperoleh dari karya ilmiah, media masa, text book, dan masih banyak lagi untuk menambah atau mendukung sumber informasi atau data yang diperlukan dalam penelitian ini dan memperkuat aspek validitas data yang dihasilkan. Peneliti akan menggali dari artikel-artikel dari berbagai sumber, termasuk internet maupun catatancatatan penting yang berkaitan dengan objek penelitian.

\section{Hasil Penelitian dan Pembahasan}

Dalam bagian ini, peneliti menguraikan tentang gambaran umum

\footnotetext{
${ }^{36}$ Baswori dan Suwandi, Memahami Penelitian Kualitatif, (Jakarta: Rineka Cipta, 1990), h. 67.
} 
lokasi penelitian dan hasil penelitian serta analisis data.

\subsection{Gambaran Umum Lokasi Penelitian}

Gereja Sidang-Sidang Jemaat Allah (GSJA) Wilayah Kabupaten Barito Timur, Kalimantan Tengah membawahi sejumlah gereja lokal, diantaranya: GSJA Marturia Tewapupu, GSJA Syalom Amparipura, GSJA Tamiang Layang, GSJA Jaar, GSJA Mangkarap, GSJA Matara, GSJA Matoli, GSJA Gumpa, GSJA Muru Duyung, GSJA Siloam Bagok, GSJA Nirwana Helang Ranu, GSJA Apar Batu, dan GSJA Jehova Jire Mabidek. Alamat sekretariat GSJA Wilayah Kabupaten Barito, Kalimantan Tengah di Jalan NansarunaiTamiang Layang, Tamiang Layang, Dusun Tim., Kabupaten Barito Timur, Kalimantan Tengah.

Penelitian ini dilakukan di 13 gereja lokal yang tergabung dalam Gereja Sidang-Sidang Jemaat Allah (GSJA) Wilayah Kabupaten Barito Timur, Kalimantan Tengah. Ke-13 gereja lokal yang dimaksudkan tersebut tergabung dalam wilayah pelayanan GSJA Kalimantan Tengah, dan merupakan bagian dari sinode GSJA.

Gereja Sidang-Sidang Jemaat Allah (GSJA) merupakan kelanjutan dari Bethel Indies Zending yang mendapat pengaku-an pemerintah pada 4 April 1941 dan kemudian namanya diubah menjadi The Assemblies of God in Indonesia yang disahkan oleh Departemen Kehakiman Republik Indonesia pada tanggal 10 Februari 1951 dengan Badan Hukum Nomor Y.A. 8/11/16. Organisasi gereja ini didirikan oleh para misionaris Amerika Serikat, Kenneth G. Short, Ralph M. Devin, Raymond Arthur Busby yang sebelumnya telah tinggal di Indonesia sebelum Perang Dunia II dan melayani sebagai misionaris dengan status swakarya dan swadana. Pada tahun 1946, Kenneth George Short, Raymond Arthur Busby, dan Ralph Mitchell Devin kembali ke Indonesia sebagai misionaris yang diutus oleh Division of Foreign Mission of the American General Council of the Assemblies of God.

Gereja Sidang-Sidang Jemaat Allah (GSJA) merupakan bagian dari Per-sekutuan Assemblies of od in the World (WAGF) yang adalah denominasi Pentakosta terbesar di dunia. Berdasarkan laporan WAGF di Portugal, GSJA dunia memiliki anggota sebanyak lebih dari 61 juta orang, di 130 negara, dengan 300.000 pelayan Injil, dan 300.000 gereja di seluruh dunia (Afrika, Asia Pacific, Eurasia, Eropa, Amerika, Amerika Latin, Karibia dan Asia bagian utara). Di Afrika sendiri terdapat sekitar 12 juta anggota, di Brazil sekitar 14-16 juta anggota, di Amerika Serikat sekitar 2,2 juta orang.

\subsection{Hasil Penelitian}

Data primer dalam penelitian ini diperoleh melalui wawancara. Wawancara dilakukan dengan menggunakan purposive terhadap 42 orang yang merupakan informan kunci, dan terdiri dari 10 orang Pendeta, 17 orang Remaja dan 15 Orang Tua.

Wawancara dilakukan dalam beberapa kesempatan dan bersifat personal dengan menggunakan daftar wawancara yang telah dipersiapkan sebelumnya oleh peneliti.

\subsubsection{Deskripsi tentang praktik okultisme pada masyarakat suku Dayak}

Maanyan yang menjadi anggota Gereja Sidang-Sidang Jemaat Allah pada wilayah Kabupaten Barito Timut 
Kalimantan tengah adalah sebagai berikut:

Pertama, Pertanyaan tentang pemahaman mengenai Okultisme. Pada waktu ditanyakan tentang pengertian okultisme kepada 10 orang pendeta yang melayani di Gereja-Gereja GSJA Kabupaten Barito Timu Kalimantan Tengah; tentang hal tersebut diperoleh hasil bahwa semuanya atau $100 \%$ pendeta, $90 \%$ dari 15 orang tua atau anggota gereja, meyakini bahwa okultisme adalah paham yang menganut dan mempraktikkan kuasa dan kekuatan dari dunia kegelapan atau dunia roh-roh jahat. Okultisme disebut juga sebagai manifestasi dari kuasa iblis yang berusaha merusak hubungan manusia dengan Tuhan Allah. Oleh karena itu, okultisme bertentangan dengan ajaran kekristenan. Namun masih terdapat sekitar $6,6 \%$ orang tua yang tidak memahami pengertian tentang okultisme.

Kedua, Pertanyaan tentang pengajar-an mengenai Okultisme di gereja, mem-berikan hasil bahwa sebagian besar pendeta atau sekitar $70 \%$ menyatakan bahwa mereka mengajarkan hal-hal yang berkaitan dengan okultisme. Tujuannya agar jemaat mampu memahami ajaran mana yang mesti dituruti sesuai dengan isi Firman Allah dan mengerti dampak negatif dari okultisme terhadap pribadi manusia maupun keluarganya. Dengan demikian, para tokoh agama berharap mereka dapat meninggalkan praktik-praktik okultisme dan penyembahan roh-roh nenek moyang yang akan meng-hambat perkembangan rohani jemaat, karena mereka terikat dengan roh-roh jahat tersebut. Contoh pengajaran tentang okultisme, seperti Penelaan Alkitab (PA) tentang topik okultisme sesuai dengan bahan dari terbitan Pustaka Sorgawi, dan bukan dari sinode. Di buku itu ada topik tentang dunia orang mati, kuasa kegelapan dan peperangan rohani. Sudah digunakan tahun 2016 secara intensif, setiap hari Selasa malam, dalam kegiatan Pendalaman Alkitab. Namun ada 20\% pendeta mengatakan bahwa hal-hal terkait okultisme tidak perlu diajarkan secara khusus, karena sudah disinggung dalam khotbah atau renungan di dalam ibadah-ibadah rutin. Alasan lain, karena sudah ada kurikulum pembinaan jemaat lewat Kelompok Pemahaman Alkitab dari Gereja Pusat. Kurikulum itu hanya men-cantumkan pengajaran doktrin Kristen seperti Alkitab dan Keselamatan. Jadi ter-gantung kebijakan gembala siding setempat. Proses pembuatan program dilakukan berdasarkan rapat bersama jemaat dan pekerja gereja. Selain itu ada seorang tokoh agama $10 \%$ yang tidak menjawab pertanyaan ini sehingga tidak jelas sikapnya.

Pada kalangan anggota gereja, yaitu orang tua, terdapat $60 \%$ orang tua yang menyatakan bahwa pendeta mereka telah memberikan pengajaran tentang okultis-me, yaitu dengan mengatakan bahwa okultisme itu merupakan dosa yang besar. Okultisme juga merupakan siasat adu domba oleh kuasa kegelapan (iblis), baik di dalam gereja maupun di dalam masyarakat. Pendeta menjelaskan bahwa orang percaya tidak boleh menyembah roh nenek moyang, atau roh-roh (penguasa) dunia, dan kalau sakit tidak boleh ke dukun. Hanya Tuhanlah yang harus disembah. Jemaat juga dilarang untuk menyembah patung atau roh-roh nenek moyang. Bila sakit tidak boleh berobat ke orang pintar (dukun). Pendeta memberikan larangan agar jemaat tidak boleh mengikuti ritualritual yang meng-atasnamakan adat, tetapi sebenarnya berisi penyembahan pada roh nenek moyang. Contoh: 
kegiatan Ipaket yang dilakukan pada setiap habis panen dengan cara memberi makan roh penjaga kampung. Pengajaran tentang okultisme biasanya diberikan pada saat khotbah ibadah hari Minggu, ibadah keluarga dan dalam kesempatankesempatan lain, seperti pada saat pertemuan jemaat dan rapat-rapat gereja. Hal ini penting sebab di desa masih banyak sekali dipraktikkan penyembahan kepada roh nenek moyang dalam agama Kaharingan. Namun ada 6 orang tua atau $40 \%$ yang mengatakan bahwa gereja dan Pendeta tidak pernah menjelaskan kepada mereka tentang apa itu okultisme dan bahaya-bahayanya.

Ketiga, Pertanyaan tentang adanya keterlibatan orang sekitar dalam praktik Okultisme. Ketika pertanyaan tentang ada-tidaknya remaja di gereja yang terlibat dalam praktik okultisme, maka di-temukan bahwa: Sekitar $40 \%$ atau empat orang pendeta yang menyatakan bahwa tidak ada remaja di gereja mereka yang terlibat dalam praktik okultisme, sebab acara adat yang berbau okultisme hanya dilakukan oleh para orang tua mereka. Namun demikian terdapat 50\% atau lima orang pendeta yang mengakui bahwa ada sebagian remaja di gereja mereka yang terlibat di dalam praktik okultisme. Misalnya: mereka ikut-ikutan dengan orang tua dalam memberikan sesajen, bersedia mempelajari ilmu atau kuasa kegelapan untuk kepentingan tertentu, seperti: jodoh dan karier serta memohon bantuan dukun atau belian ketika mereka menghadapi masalah dalam hidup ini. Faktor yang menyebabkan selain karena faktor lingkungan keluarga, juga karena masih kurangnya pemahaman para pemuda tentang bahaya okultisme. Satu orang hamba Tuhan atau $10 \%$ tidak memberi jawaban sehingga tidak jelas tanggapannya atas pertanyaan yang dimaksud.

Pertanyaan yang sama diajukan kepada para orang tua yang adalah anggota gereja, diperoleh hasil bahwa $33,4 \%$ mengakui bahwa masih ada teman-teman di gereja mereka yang terlibat dalam praktik okultisme. Hal ini terjadi karena minimnya pengetahuan pemuda tentang bahaya okultisme dan juga karena pengaruh negatif dari pergaulan muda-muda di dalam masyarakat. Contohnya adalah pemuda ikut berjudi, merokok, miras, suka melawan orang tua, tidak suka beribadah, dan sejenisnya. Semua tindakan tersebut mungkin karena akibat keterlibatannya dalam okultisme. Masih ada pula pemuda yang terikat dengan sahur atau ikatan dengan roh nenek moyang, sehingga dia harus melakukan ritual memberi makan nenek moyang setahun sekali, khususnya setelah kegiatan panen. Pada beberapa pemuda tertentu yang masih terikat dengan adat istiadat nenek moyang, mereka masih suka memberikan per-sembahan atau sesajen ke roh-roh, walau mereka tahu hal itu tidak dibenarkan oleh Alkitab. Namun demikian sebagian besar orang tua atau sekitar $66,6 \%$ menyatakan bahwa tidak ada teman di geeja mereka atau di gereja tetangga yang terlibat dalam praktik okultisme, sebab mereka telah mengenal siapakah Tuhan Yesus itu. Jadi hidup mereka sungguh percaya dan bersandar hanya pada Tuhan Yesus saja.

Keempat, Pertanyaan tentang pengalaman keterlibatan dalam praktik Okultisme. Ketika pertanyaan ini diajukan, nyata bahwa $40 \%$ atau empat orang pendeta menyatakan bahwa mereka tidak pernah terlibat dalam segala macam bentuk praktik okultisme. Namun ada lima orang atau $50 \%$ pendeta yang me-ngakui bahwa mereka dahulu 
pernah terlibat dalam kegiatan okultisme, karena mereka lahir dan dibesarkan dalam keluarga yang bukan Kristen karena masih percaya pada keyakinan Kaharingan; atau yang belum mengenal Tuhan Yesus dengan sungguhsungguh. Jadi pada waktu orang tua atau keluarga mereka membawa sesajen atau me-nyembah roh-roh, maka mereka pun ikut serta dalam kegiatan itu. Contoh, pada kecil, mereka mengikuti ritualritual adat seperti Tampung Tawar dan tarian Ngajan dalam upacara Tiwah. Selain itu ada seorang pendeta atau 10\% yang tidak menjawab pertanyaan ini.

Sebagian kecil orang tua atau sekitar 26,7\% saja yang mengaku bahwa dia pernah terlibat di dalam praktik okultisme, khususnya pada saat dia belum mengenal jalan kebenaran di dalam Yesus Kristus. Hal itu terjadi ketika belum mengenal Kristus, masih percaya kepada roh-roh nenek moyang, sehingga setiap tahun selalu pergi ke pohon-pohon besar untuk mengantar sesajen kepada roh yang dipercaya dapat menjaga kampung dan memberkati keluarga. Namun demikian sebagian besar orang tua atau $73,3 \%$ menyatakan bahwa diri mereka tidak pernah sekalipun terlibat dalam praktik okultisme, sebab mereka telah percaya kepada Yesus Kristus sebagai Tuhan dan Juru Selamat.

Kelima, Pertanyaan tentang contoh-contoh praktik Okultisme yang pernah diperbuat. Pada saat pertanyaan ini diaju-kan, sebagian besar tokoh agama yaitu sekitar $80 \%$ dapat menjelaskan seperti apa contoh praktik okultimse yang terjadi di sekitar wilayah pelayanan mereka. Hanya dua orang atau $20 \%$ yang tidak menjawab dengan jelas atau tidak mem-berikan contoh praktik okultisme yang mereka ketahui. Adapun contoh-contoh dari praktik okultisme yang masih berlangsung hingga kini adalah: (1) Belian yaitu pemujaan kepada roh-roh yang sudah meninggal, (2) Ipaket yaitu pemujaan kepada rohroh nenek moyang, (3) Marabian yaitu kegiatan mengantar arwah dari orang yang sudah meninggal dunia ke kuburan adat, (4) Memiliki ilmu kekebalan dan memberikan sesajen pada roh-roh di pohon-pohon besar, (5) Melakukan pantangan-pantangan tertentu, karena dilarang oleh nenek moyang. Pantanganpantangan di dayak Maanyan: tidak boleh makan makan tertentu, semacam makanan haram dan halal. Misalnya: keturunan tertentu tidak boleh makan ikan atau hewan tertentu. Alasan, bila dimakan, nanti ada keluarga yang sakit. Jangan membawa telur dalam mobil, baik telor mentah maupun masak. Alasannya: karena telur itu makanan hantu. Bila telur dibawah dengan mobil, maka takut terjadi apa-apa dengan keluarga. Seringkali upacara adat, arwah-arwah diberi makan telur. Bila beli mobil baru, maka harus pecahkan telur di depan mobil. Tidak boleh potong kuku atau rambut di malam hari. Berbahaya, karena usia dapat pendek.

Praktik Balian atau Belian, yang khusus untuk orang Dayak Maanyan, dikenal sebagai orang yang melakukan atau memimpin kegiatan upacara adat.

Ada macam-macam balian, yaitu:

(1) Balian Dusun yaitu balian perempuan untuk memberi makan arwah nenek moyang. Balian Dusun memberi makan arwah nenek moyang dengan cara mem-bawa sesajen berupa: lemang, daging babi, daging ayam, rokok, tuak dan sejenisnya yang merupakan kebiasaan almarhum di waktu hidup dan dibawah ke kuburan, seperti: pohon kayu besar untuk laki-laki, dan guci untuk arwah perempuan. Pohon besar itu ditandai dengan tanaman daun sawang. 
Pohon ter-sebut disebut panangkulan. Cirinya harus pohon besar dan kokoh, rimbun. Guci di dalam rumah itu disebut bangah, yang artinya guci. Guci itu adalah guci khusus yang sudah kuno dari tanah liat dan bukan keramik. Satu guci dapat diisi oleh satu keluarga yang perempuan saja. Balian Dusun memberi makan arwah nenek moyang. Caranya: membawa sesajen yaitu: lemang, daging babi atau daging ayam, rokok, tua dan sejenisnya yang merupakan kebiasaan almarhum di waktu hidup; ke tempat kuburan seperti: pohon kayu besar untuk laki-laki, dan guci untuk arwah perempuan. Pohon besar itu ditandai dengan tanaman daun sawang. Pohon tersebut disebut panangkulan. Cirinya harus pohon besar dan kokoh, rimbun. Jadi dapat jenis pohon apa saja. Satu pohon hanya untuk satu keluarga, yaitu bapak dan anak lelaki. Sisi positif, semakin banyak keluarga, maka semakin banyak pohon besar terlindungi. Guci di dalam rumah itu disebut bangah, yang artinya guci. Guci itu adalah guci khusus yang sudah kuno dari tanah liat dan bukan keramik. Satu guci dapat diisi oleh satu keluarga yang perempuan saja. Isi guci kosong, tetapi berisi roh halus yaitu arwah orang tua. Profesi balian diperoleh dari berguru, bukan diwariskan. Mereka harus lulus dari ujian tertentu. Mereka menguasai banyak mantera yang telah dihafal; (2) Balian Dadas, yaitu balian perempuan yang bertugas menyembuhkan orang yang sakit dan ucapan syukur; (3) Balian Bawo yaitu balian laki-laki untuk kegiatan upacara menjaga rumah dari marabahaya dan memberi makan sahor yaitu sesuatu yang dapat melindung rumah dari roh nenek moyang; (4) Balian Amun Raho yaitu balian perempuan yang bertugas untuk melaksanakan ritual nazar keluarga yang bersangkutan, misalnya: nazar bila berhasil atau sukses dalam kehidupan, dan untuk suku Dayak Maayan, Balian ini adalah balian yang tertua, atau yang pertama atau asli di Dayak Maanyan. (5) Balian Diwa, yaitu balian perempuan yang bertugas untuk memberi makan roh halus yang ada di dalam rumah Diwa, yaitu sebuah rumah kecil yang ditempatkan di dalam rumah. Balian Diwa memakai bahasa Banjar, walaupun dia adalah orang Maanyan, sebab dayak Maanyan dan dayak Banjar itu masih saudara. Dayak yang lebih tua adalah dayak Maanyan, sebab dayak Banjar kebanyakan suku Melayu. Asal usul tempat dayak Maanyan adalah dari daerah ulin dan kayutangi di Banjarmasin, lokasi di mana mayoritas Kristen berada. Daerah ini masuk wilayah kota Banjarmasin. Setelah masuk kerajaan Islam, orang Dayak tidak suka kasar-mengasar, maka orang Dayak ber-geser ke pegunungan untuk bertahan hidup dan pindah ke wilayah Barito. Kemungkinan nenek moyang juga berasal dari suku Melayu. Balian atau dukun berhubungan dengan roh-roh. Balian itu mengantar roh orang mati, dengan nama sorganya adalah Dato Tonyong. Setelah orang mati, tiga tahun dipanggil lagi, sebab sebelumnya roh ada di dato tonyong. Ditaruh di pohon kayu. Itulah kegiatan Marabia. Setelah tiga tahun dilakukan Marabia wajib dilakukan lagi kegiatan dengan nama Nuang Panuk tahun 1 selama 3 tahun berturut-turut. Masyarakat Dayak Maanyan harus ber-ladang, sebab beras ketan dan bekal yang lain adalah hasil dari kebun atau ladang sendiri. Tidak boleh pinjam dari orang lain. Bila yang meninggal anak-anak, maka orang tua yang harus melakukan ritual. Jika melakukan ritual Nuang Panuk maka mereka tidak mendapat tempat istimewa di dato tonyong. Roh nenek moyang 
dipercaya dapat menjadi pelindung, semacam Tuhan bagi mereka. Tugas keluarga selanjutnya adalah memberi makan, atau sesajen ke roh yang telah menjadi pelindung tersebut. Misalnya: memberikan sesajen setelah selesai panen. Keluarga dari yang mati harus terlibat di dalam kegiatan ibadah tersebut. Sarana yang digunakan bernama Nana, yang berisi macam kue, lemang, dan sebagainya. Semua diserahkan itu akan menjadi bekal bagi yang mati di dunia dato tonyong. Dibuat patung yang menyerupai orang yang telah meninggal, lalu dikeliling oleh kerbau; yang dianggap memiliki roh. Kerbau tersebut harus berkeliling sebanyak sebanyak tujuh kali, lalu kemudian ditombak oleh keluarga dan ditangisi seperti halnya orang tua mereka yang mati.

Upacara Marabia adalah kegiatan mengantar arwah ke tempat khusus yang bernama Batu Tunjung atau tempat yang kaya, yaitu semacam sorga. Mereka membuat Bator, yaitu kayu ulin yang dibuat semacam batu nisan dan diukir dengan motif bunga dan guci. Bator itu di atas kuburan tanah, tanpa tulisan identitas. Kuburan agama kaharingan terpisah dengan kuburan Islam dan Kristen. Marabia adalah sebuah ritual yang paling tinggi, seperti menghantar orang tua ke Mekkah atau surga. Dilaksanakan tiga hari tiga malam oleh Balian Matei, yaitu seorang balian perempuan. Marabia juga dapat dilakukan hingga lima hari. Paling sedikit oleh tiga balian. Di tambah lagi acara nyambung ayam dan judi. Lalu ditutup dengan potong satu ekor kerbau. Balian ini sudah hampir punah. Ada dua jenis roh, yakni roh-roh lain dan roh-roh nenek moyang. Yang bahaya adalah rohroh dari dunia lain, yang dapat mengakibat-kan bencana, kelaparan, dll.
Ini yang sulit dilepas. Ritual untuk memberi makan roh jenis ini adalah kegiatan Ipaket. Ada kegiatan nyepi sehari pada setiap tahun dan kegiatan ini juga melibatkan orang-orang Kristen. Jadi ketakutan orang Kristen tidak kepada roh leluhur, melainkan kepada roh-roh lain. Misalnya: ada seorang kerasukan atau sakit, maka ada kayu atau pohon tertentu yang harus diberi makan.

Dahulu, orang Dayak percaya orang yang mati itu pergi ke hutan dan meng-hilang. Kalau seorang Marabia, maka dia bisa buat kuburan sendiri dengan rumah dan hiasan. Kalau tidak mampu Marabia, maka yang mati harus numpang di kuburan yang sudah di Marabia-kan. Bagi dayak lawangan di daerah Ampah, orang mati akan ditaruh di peti dan pohon. Wilayah Dayak Maanyan tersebar di ber-bagai tempat. Asal usul dari dari kerajaan kayutangi dari Banjarmasin. Ada kuburan putri Maanyan yang hingga kini dikunjungi oleh orang Banjar dan orang Maanyan. Orang-orang Kristen sering terjebak dengan lokasi tersebut. Kalau di gereja, masih ada warga yang mungkin terlibat, di antaranya lewat kegiatan tarian-tarian tertentu, yang dipandang bersifat kebudayaan semata.

Kegiatan Ipaket yang dilaksanakan setiap habis panen, sekitar bulan Juli. Tujuannya untuk memberi makan roh penjaga kampung yang disebut miwit alah paket. Kegiatan yang dilakukan membuat bubur putih yang melambangkan kebaikan, bubur merah yang melambangkan pengorbanan. Lalu panggang ayam kampung, kue tradisional sebanyak 41 macam, lemang atau pakinkin yaitu nasi yang dimasak dalam bambu. Ditaruh pada ancak yaitu tempat sesajem besar, dikumpul. Kegiatan yang dilakukan: (1) Pada malam Jumat, dilakukan kegiatan 
memberi makan miwit alah paket oleh Balian putut kayo, seorang laki-laki. Ada ritual khusus. Setelah itu makan bersama dari ancak tersebut. (2) sekitar jam 24.00 , peserta pulang ke rumah dengan mem-bawa ancak yaitu tempat sesajen kecil untuk ditaruh di teras rumah, sebagai tanda sudah melaksanakan ritual dan bedak untuk dioleskan pada waktu itampadi pisan atau Nyepi. (3) Setelah itu dilakukan kegiatan Nyepi pada hari Jumat, mulai pagi hingga malam, disebut itampadi pisan, yang artinya tidak boleh melakukan pekerjaan selama satu hari penuh. Nyepi berakhir pada jam tujuh malam.

Sebagian besar orang tua di gereja dapat menjelaskan contoh dari praktikpraktik okultisme yang ada di dalam kehidupan mereka sehari-hari. Misalnya: (1) Praktik Balian, khususnya pengobatan mengunakan kuasa (roh) nenek moyang dan kuasa kegelapan, (2) Membawa se-sajen ke pohon keramat masih, setelah selesai panen. Contoh: kegiatan miempu, itangai dan miwit allah yaitu kegiatan memberi makan atau sesajen kepada roh-roh nenek moyang setiap tahun, sehabis panen. (3) Penyembahan berhala, sembah roh nenek moyang, sembah penguasa alam, sembah tempat-tempat keramat. Selain itu percaya kepada roh peperangan adalah keyakinan yang masih kuat di kalangan suku Dayak Maanyan. (4) Aksi tindakan menguna-gunai orang lain dengan mengambil helai rambut dari orang yang hendak disantet, lalu dirajam di kuburan atau pohon besar, agar sang pemilik rambut menjadi sakit dan menderita, (5) Mengikut upacara Marabia, dan (6) Pengunaan jimat dalam bentuk penglaris atau pesugihan dan dapat juga berupa susuk. Contohnya jimat minat sula yaitu menghilangkan rasa sakit dengan mengoleskan tubuh yang sakit dengan minyak yang telah dijampijampi. Hanya sebagian kecil orang tua $(20 \%)$ yang tidak bisa menjelaskan contoh dari praktik-praktik okultisme di dalam kehidupan mereka sehari-hari.

Keenam, Pertanyaan tentang dampak yang ditimbulkan dalam praktik Okultisme. Ketika pertanyaan ini diajukan maka sebagian besar pendeta atau sekitar $90 \%$ mampu menjelaskan dampak buruk dari praktik okultisme bila hal itu masih terjadi di dalam gereja. Misalnya: (1) Hilangnya damai sejahtera dan tidak akan ada pertumbuhan rohani, (2) Terikat atau tergantung dengan kuasa kegelapan. Jemaat akan terikat oleh perdukunan, sehingga kemerosotan moral akan semakin meningkat. (3) Terjadi ke-merosotan sosial dalam relasinya dengan orang lain dan komunikasi dengan lingkungan menjadi terputus atau rusak. (4) Manusia akan terjebak dalam tipu daya Iblis. Adanya kutuk yang mengikat. Jemaat akan sulit melepaskan diri dari kuasa jahat dan terikat untuk melakukan praktik okultisme yang harus dilakukan setiap tahun. (5) Hidupnya semakin sengsara dan melarat, karena setiap tahun kita dituntut untuk memberikan persembahan sesajen kepada roh-roh. Bila tidak memberi, maka kita bisa sakit, gila hingga meninggal dunia. (6) Praktik perjudian merajalela, banyak terlibat perselingkuhan dan perceraian semakin meninggkat. Jemaat juga menjadi malas ke gereja. Hanya satu orang tokoh agama atau $10 \%$ yang tidak menjawab pertanyaan ini. Jadi tidak jelas seberapa jauh pemahaman beliau tentang dampak buruk dari praktik okultisme.

Sebagian besar orang tua atau sekitar 73,3\% mengatakan bahwa praktik Okultisme itu memiliki dampat nyata dalam kehidupan sehari-hari maupun 
dalam kehidupan sebagai orang beriman kepada Yesus. Beberapa dampak dalam kehidupan sehari-hari adalah: (1) Muncul penyesalan ketika dia sadar; (2) Menjadi orang yang suka marah-marah; (3) Mudah kesurupan; (4) Sering marahmarah; (5) Hidupnya akan selalu ditempa masalah, seperti sakit penyakit dan musibah; (6) Menimbulkan korban yang sakit secara fisik; (7) Kalau sakit, orang tersebut lebih percaya untuk berobat ke dukun atau balian daripada pergi ke dokter atau perawat; dan (8) Dapat me-ngakibatkan kematian pada seseorang. Sedangkan dampak okultisme terhadap kehidupan beriman, di antaranya: (1) Hidup orang tersebut akan terikat, mau tidak mau harus memberikan persembah-an atau sesajen, setiap kali habis panen atau pada saat bulan baru; (2) Mereka akan terikat dan tergantung pada kuasa kegelapan; (3) Hidup orang itu akan semakin jauh dari Tuhan; (4) Me-nimbulkan korban yang sakit secara rohani, hingga konflik batin dan dengan sesama; (5)

Kehidupan akan penuh dengan penderitaan, curiga dengan sesama atau tetangga dan hidup pribadi semakin dipenuhi dengan ketakutan; (6) Bila orang itu lalai dalam memberikan persembahan, maka akan terjadi kerugian di dalam keluarganya. Misalnya: ada anggota keluarga yang sakit, atau ke-surupan roh-roh. Hanya empat orang tua atau sekitar $26,7 \%$ yang tidak menjawab apa dampak dari okultisme terhadap kehidupan orang yang percaya kepada Yesus Kristus.

Ketujuh, Pertanyaan tentang upaya pembimbingan khusus bagi orang yang terlibat dalam praktik Okultisme. Pada saat pertanyaan ini diajukan maka lebih dari separuh pendeta atau $70 \%$ memberikan masukan dan pengajaranpengajaran rohani agar mereka tidak tidak terjebak ke dalam okultisme. Pembinaan dilakukan dalam bentuk penjelasan bahwa praktik okultisme bertentangan dengan firman Tuhan dan jemaat harus berusaha terhindar dari tipu muslihat iblis. Jemaat juga dijelaskan tentang doktrin keselamatan untuk memberikan kepastian kepada jemaat dalam hidupnya di dunia ini dan di akhirat, sehingga mereka tidak perlu takut kepada roh-roh nenek moyang lagi. Ada dilakukan pembimbingan supaya mereka yang terikat dapat lepas dari ikatan Iblis dan mengalami kemerdekaan serta keselamatan di dalam Yesus. Khusus bagi jemaat tertentu yang sudah terikat dalam okultisme, para tokoh agama akan melakukan pelayanan pe-lepasan atau exorcism. Pelayanan Okultisme lebih banyak dilakukan kepada jemaat di luar gereja lokal. Pada saat dia ingin ikut Tuhan sungguhsungguh, roh-roh atau arwah akan melawan, sehingga harus dilakukan pelepasan. Biasa orang yang datang sendiri untuk dilayani. Biasanya mereka memakai jimat, seperti: akar, pisau, keris, susuk atau minyak-minyak yang pernah diminum. Namun ada dua tokoh agama atau $20 \%$ yang menyatakan bahwa mereka tidak melakukan pembimbingan khusus tentang Okultisme sebab tidak ada pemuda di jemaat mereka yang terlibat. Menurut mereka, bila terjadi kerasukan, maka hal itu biasanya dari jemaat gereja lain dan atau yang bukan Kristen. Misalnya pada kegiatan semacam Youth Camp mungkin saja terjadi kerasukan warga GSJA, tetapi dari gereja lokal GSJA yang mereka layani. Bila terjadi, maka biasanya pendeta dari pemuda tersebutlah yang akan membimbing anak tersebut. Hanya satu orang tokoh agama atau $10 \%$ yang tidak menjawab pertanya-an ini. Jadi tidak jelas seperti 
apa proses pembimbingan yang beliau lakukan bila ada jemaat yang terjerat praktik okultisme di gerejanya.

Sebagian besar orang tua di gereja atau sekitar $66,7 \%$ menyatakan bahwa ada pembimbingan khusus bagi para remaja yang telah atau pernah terjerat dalam praktik okultisme. Cara-cara yang dilakukan gereja, seperti: (1) Penjelasan mengenai bahaya dari penyembahan berhala yang disampaikan secara rinci, khususnya yang ada di dalam penyembahan di kalangan suku Dayak Maanyan; (2) Gereja melarang melakukan hal-hal yang bertentangan dengan Firman Tuhan, seperti: tidak boleh merokok, berjudi dan menyembah patung; (3) Para orang tua juga diminta oleh gereja untuk melarang anakanaknya agar tidak mengikuti praktik penyembah-an berhala; (4) Ada pembimbingan khusus, sehingga jemaat berani menolak ketika diberikan air untuk anak mereka yang sakit. Jemaat juga diajar untuk mampu menolak ikut melakukan ritual yang bertujuan untuk menyembuhkan sakit atau memberi kebaikkan. Tujuan dari pembimbingan adalah agar jemaat mendapat pengetahuan tentang ajaran yang benar, dibimbing untuk dapat membedakan segala sesuatu dengan bijak berdasarkan kebenaran Firman Tuhan, sehingga mereka tidak terjerumus lagi ke dalam praktik okultisme, yang akan sangat merugikan jiwa mereka. Hanya sebagian kecil orang tua atau 33,3\% yang mengatakan bahwa gereja dan Pendeta tidak pernah melakukan bimbingan khusus bagi jemaat atau pemuda yang pernah terjerat praktik okultisme.

\subsubsection{Deskripsi tentang praktik okultisme secara khusus pada remaja suku}

Dayak Maanyan yang menjadi anggota Gereja Sidang-Sidang Jemaat Allah pada wilayah Kabupaten Barito Timut Kalimantan tengah adalah sebagai berikut:

Pertama, Pertanyaan tentang pemahaman mengenai Okultisme. Pada waktu ditanyakan tentang pengertian Okultisme kepada 17 remaja, dan hasilnya menyatakan bahwa 94,2\% remaja setuju dan sepakat bahwa Okultisme adalah paham yang menganut dan mem-praktikkan kuasa dan kekuatan dari dunia kegelapan atau dunia roh-roh jahat. Okultisme disebut juga sebagai manifes-tasi dari kuasa iblis yang berusaha merusak hubungan manusia dengan Tuhan Allah. Oleh karena itu, okultisme berten tangan dengan ajaran kekristenan. Namun demikian ada 5,8\% para remaja yang tidak memahami pengertian dari okultisme.

Kedua, Pertanyaan tentang pengajar-an mengenai Okultisme di gereja. Pada pertanyaan kedua ditanyakan maka 53,3\% remaja menyatakan bahwa pendeta atau pembina rohani mereka sudah mengajarkan hal-hal yang ber-kaitan dengan okultisme di gereja mereka. Okultisme dijelaskan sebagai hal-hal yang berhubungan dengan roh-roh atau dunia gaib dan bertentangan dengan firman Tuhan. Namun demikian, masih terdapat $46,7 \%$ remaja yang menyatakan bahwa pendeta atau pembina rohani tidak pernah mengajarkan hal-hal yang ber-kaitan dengan okultisme di gereja mereka.

Ketiga, Pertanyaan tentang keterlibatan orang sekitar dalam praktik Okultisme. Ketika pertanyaan tentang ada-tidaknya remaja di gereja yang terlibat dalam praktik okultisme, maka di-temukan bahwa sebagian besar remaja atau sekitar 73,3\% mengaku bahwa ada teman-temannya baik dari gerejanya 
maupun di lingkungan sekitarnya; terlibat dalam praktik okultisme. Beberapa contoh keterlibatan dari remaja gereja adalah: (1) Ikut kegiatan perdukunan; (2) Melakukan penyembahan kepada leluhur atau rohroh nenek moyang; (3) Memberi makan kepada hantu; (4) Jika ada yang sakit, maka mereka akan mengadakan ritual memanggil roh-roh untuk menyembuhkan si sakit; dan (5) Masih mengunakan ilmu hitam atau percaya pada kekuatan roh nenek moyang untuk tujuan tertentu. Hanya sebagian kecil pemuda atau sekitar $26,7 \%$ yang menyatakan bahwa tidak ada temantemannya baik dari gerejanya maupun dari gereja tetangga yang terlibat dalam praktik okultisme. Dengan kata lain, menurut mereka, jemaat di gerejanya bersih dari praktik okultisme dan sejenisnya.

Keempat, Pertanyaan tentang pengalaman keterlibatan dalam praktik okultisme. Ketika pertanyaan ini diajukan, nyata bahwa sekitar 33,3\% yang me-ngaku bahwa mereka pernah terlibat dalam praktik okultisme. Walaupun tidak diceritakan contohnya, hal ini tetap saja mengejutkan bila mereka adalah para remaja yang telah dilahirkan dan dibesarkan di dalam keluarga yang telah beragama Kristen. Namun sebagian besar remaja atau sekitar $66,7 \%$ menyatakan bahwa mereka tidak pernah terlibat dalam praktik okultisme.

Kelima, Pertanyaan tentang contoh-contoh praktik Okultisme yang pernah di-perbuat. Pada saat pertanyaan ini diaju-kan, sebagian besar pemuda atau sekitar 94,2\% memceritakan dan memberikan praktik-praktik okultisme yang terjadi di sekeliling mereka. Misalnya: (1) Praktik perdukunan (balian); (2) Praktik me-manggil roh-roh kegelapan; (3) Mem-pelajari ilmu-ilmu setan (kegelapan) ilmu-ilmu sihir; (4) Memberi makan hantu (roh-roh); (5) Menyembah setan; (6) Memberikan makan hantu; (7) Me-lakukan kasarung yaitu memanggil roh-roh untuk memasuki tubuh; (8) Miliki ilmu atau jimat untuk memikat perempuan; dan (9) Mengikui kegiatan ijame yakni pembakaran mayat. Hanya ada seorang pemuda saja atau sekitar 5,8\% yang tidak menjawab sehingga tidak bisa memberikan contoh dari praktik-praktik okultisme yang yang pernah terjadi di sekelilingnya.

Keenam, Pertanyaan tentang dampak yang ditimbulkan dalam praktik Okultisme. Ketika pertanyaan ini diajukan maka sebagian besar remaja atau sekitar 88,3\% mengerti dan mampu menjelaskan dampak dari berbagai praktik okultisme yang terjadi di sekitar mereka. Contohnya adalah: (1) Pergi berobat pada roh-roh kegelapan lewat Balian; (2) Orang tersebut akan meragukan pada yang tertulis dalam Alkitab; (3) Mereka akan terjerumus dan terjerat dalam kuasa kegelapan; (4) Mereka ke-takutan bila menghadapi rohroh jahat; (5) Roh-roh yang dipanggil itu akan me-rasuki hidup manusia atau terjadi kesurupan pada orang tertentu; (6) Hidup mereka akan semakin jauh dari Tuhan; (7) Mereka akan semakin terjebak di dalam dosa dan menjadi budak setan atau dosa; dan (8) Muncul ancaman, sebab bila tidak dilakukan ritual penyembahan, maka keluarga yang bersangkutan akan mengalami ketakutan, sakit-sakitan, bahkan akan kerasukan roh-roh halus. Namun ada dua orang remaja atau $11,7 \%$ dari jumlah para remaja yang diwawancarai yang tidak dapat menjelaskan apa dampak dari praktik okultisme dalam kehidupannya sehari-hari. 
Ketujuh, Pertanyaan tentang upaya pembimbingan khusus bagi orang yang terlibat dalam praktik Okultisme. Pada saat pertanyaan ini diajukan ada sekitar $35,2 \%$ remaja yang berkata bahwa gereja melakukan pembimbingan khusus kepada para remaja yang terjerat dalam praktik okultisme. Bentuknya adalah doa pelapasan bagi pribadi-pribadi yang telah terikat kuasa gelap dan pengajaran tentang bahasa okultisme di gerejanya masing-masing. Namun demikian, sebagian besar remaja, yaitu sekitar $64,8 \%$ mengaku bahwa tidak ada pembimbingan khusus bagi para pemuda atau teman-teman mereka yang telah atau pernah terjerat dalam praktik okultisme. Sayangnya para remaja ini tidak menyampaikan alasan mengapa gereja tidak memberikan pembimbingan khusus.

\subsection{Analisis Data}

a. Pertanyaan tentang bagaimanakah gambaran praktik okultisme secara umum dalam kehidupan suku Dayak Maanyan, sebagaimana yang ditanyakan pada bagian pendahuluan; dapat terlihat sebagai berikut, yaitu:

Balian, yaitu dukun yang pada umumnya menjadi pemimpin pemujaan terhadap orang-orang yang sudah meninggal. Suku Dayak Maanyan pada umumnya mengenal beberapa macam belian, diaantaranya adalah: Balian Dusun yaitu balian perempuan memimpin upacara memberi makan arwah nenek moyang; Balian Dadas, yaitu balian perempuan yang bertugas menyembuhkan orang yang sakit dan ucapan syukur; Balian Bawo yaitu balian laki-laki untuk kegiatan upacara menjaga rumah dari marabahaya dan memberi makan sahor yaitu sesuatu yang dapat melindung rumah dari roh nenek moyang; Balian Amun Raho yaitu balian perempuan yang bertugas untuk melaksanakan ritual nazar keluarga yang bersangkutan, misalnya: nazar bila berhasil atau sukses dalam kehidupan, dan untuk suku Dayak Maayan, Balian ini adalah balian yang tertua, atau yang pertama atau asli di Dayak Maanyan; Balian Diwa, yaitu balian perempuan yang bertugas untuk memberi makan roh halus yang ada di dalam rumah Diwa, yaitu sebuah rumah kecil yang ditempatkan di dalam rumah.

Ipaket yaitu pemujaan kepada rohroh nenek moyang, dan kegiatan Ipaket yang dilaksanakan setiap habis panen, sekitar bulan Juli. Tujuannya untuk memberi makan roh penjaga kampung yang disebut miwit alah paket. Kegiatan yang dilakukan membuat bubur putih yang melambangkan kebaikan, bubur merah yang melambangkan pengorbanan. Lalu panggang ayam kampung, kue tradisional sebanyak 41 macam, lemang atau pakinkin yaitu nasi yang dimasak dalam bambu. Ditaruh pada ancak yaitu tempat sesajem besar, dikumpul. Kegiatan yang dilakukan dalam urut-urutan kegiatan upacara sebagai berikut: Pada malam Jumat, dilakukan kegiatan memberi makan miwit alah paket oleh Balian dengan ritual khusus. Setelah itu makan bersama dari ancak, yaitu tempat sesajen. Sekitar jam 24.00, peserta pulang ke rumah dengan membawa ancak untuk ditaruh di teras rumah, sebagai tanda sudah melaksanakan ritual dan bedak untuk dioleskan pada waktu Itampadi pisan atau Nyepi. Istilah Itampadi pisan itu sendiri memiliki arti tidak boleh melakukan pekerjaan selama satu hari penuh. Setelah itu dilakukan kegiatan Nyepi pada hari Jumat, mulai pagi hingga malam, disebut itampadi pisan, yang artinya tidak boleh melakukan pekerjaan selama satu hari penuh. Nyepi 
berakhir pada jam tujuh malam.

Marabia yaitu kegiatan mengantar arwah dari orang yang sudah meninggal dunia ke kuburan adat, arwah orang yang meninggal itu diantar ke tempat khusus yang bernama Batu Tunjung atau tempat yang kaya, yaitu semacam sorga. Mereka membuat Bator, yaitu kayu ulin yang dibuat semacam batu nisan dan diukir dengan motif bunga dan guci. Bator itu di atas kuburan tanah, tanpa tulisan identitas. Marabia adalah sebuah ritual yang paling tinggi, seperti menghantar orang tua ke Mekkah atau surga. Dilaksanakan tiga hari tiga malam oleh seorang balian perempuan. Marabia juga dapat dilakukan hingga lima hari. Paling sedikit oleh tiga balian. Di tambah lagi acara nyambung ayam dan judi. Lalu ditutup dengan potong satu ekor kerbau.

Selain hal-hal di atas, ada juga halhal lain yang memiliki kaitan dengan okultisme, yaitu: Memiliki ilmu kekebalan dan memberikan sesajen pada roh-roh di pohon-pohon besar, Melakukan pantangan-pantangan tertentu, karena larangan secara turuntemurun. Dalam tradisi masyarakat Dayak Maayan, ada pantanganpantangan tertentu yang harus dilakukan, misalnya: tidak boleh makan makan tertentu, semacam makanan haram dan halal, seperti keturunan tertentu tidak boleh makan ikan atau hewan tertentu. Dilarang membawa telur dalam mobil, baik telor mentah maupun masak, sebab telur itu makanan hantu; dan jika telur dibawah dengan mobil, maka takut terjadi apa-apa dengan keluarga. Jika membeli mobil baru, maka harus pecahkan telur di depan mobil. Tidak boleh potong kuku atau rambut di malam hari. Berbahaya, karena usia dapat pendek.

b. Pertanyaan tentang bagaimana praktik okultisme dikalangan Remaja di Gereja Sidang-Sidang Jemaat Allah (GSJA) Wilayah Kabupaten Barito Timur Kalimantan Tengah, terungkap bahwa masyarakat Dayak Maayan merupakan masyaakat yang masih memegang teguh prinsipprinsip kepercayaan lokal, walaupun mereka telah menjadi Kristen.

Ada $80 \%$ anggota gereja dewasa yang memahami dengan jelas tentang tradisi dan praktik upacara yang sarat dengan okultisme dalam kehidupan mereka sehari-hari, dan bahkan 94,2\% remaja dapat menceritakan dan memberikan contoh tentang praktik okultisme yang biasa terjadi di lingkungan sekitar mereka.

Dalam wawancara yang dilakukan terungkap bahwa para remaja memahami praktik okultisme yang umumnya dilaku-kan, yaitu: Praktik perdukunan; Praktik memanggil roh-roh kegelapan; Mem-pelajari ilmu-ilmu setan atau ilmuilmu sihir; Memberi makan hantu (rohroh); Menyembah setan; Memberikan makan hantu; Melakukan kasarung yaitu me-manggil roh-roh untuk memasuki tubuh; Memiliki jimat untuk memikat perempuan; dan mengikui kegiatan ijame yakni pembakaran mayat. Padahal Alkitab dengan jelas menegaskan bahwa: Janganlah kamu melakukan telaah atau ramalan ... Janganlah kamu berpaling kepada arwah atau kepada rohroh peramal; janganlah kamu mencari mereka dan dengan demikian menjadi najis karena mereka; Akulah TUHAN Allahmu (Im.19:26b,31), perilaku orang percaya dalam menjalani kehidupannya harusnya hanya bersama dengan Tuhan.

Ketika dalam wawancara kepada pendeta tentang dugaan keterlibatan remaja di gereja mereka dalam praktik okultisme, ditemukan $50 \%$ atau lima pendeta menyatakan bahwa ada sebagian 
remaja di gereja mereka yang terlibat dalam praktik okultisme. Keterlibatan itu berupa: Ikut-ikutan dengan orang tua dalam memberikan sesajen; bersedia mempelajari ilmu atau kuasa kegelapan untuk kepentingan tertentu seperti: jodoh dan karier ; serta memohon bantuan dukun atau belian ketika mereka menghadapi masalah dalam hidup. Juga karena lingkungan tempat tinggal dan bahkan keluarga para remaja yang membuat mereka terlibat dalam praktik okultisme.

Pengakuan beberapa remaja berinisial: Ke, yang menyatakan bahwa ia pernah terlibat praktek okultisme; $\mathrm{Ru}$, yang mengikuti ritual Tampung Tawar dan tarian Ngajan dalam upacara Tiwah; $\mathrm{Su}$, yang terlibat dalam praktik okultisme sewaktu belum bergereja dan $\mathrm{Sp}$, yang terang-terangan mengakui bahwa ia masih ikut praktik Okultisme karena kedua orang tuanya masih beragama Kaharingan sehingga mau tidak mau ia ikut di dalam berbagai upacara. Artinya dari 17 remaja yang diwawancarai, terdapat tiga orang, yaitu: $\mathrm{Ke}, \mathrm{Ru}$ dan $\mathrm{Su}$, yang pernah terlibat dalam praktik Okultisme, sementara satu orang, yaitu Sp yang hingga kini masih terlibat dalam praktik berhala tersebut. Okultisme sebagaimana yang dikatakan Kurt Koch adalah adalah paham atau kepercayaan terhadap alam superanatural, misterius, gaib, dengan berbagai sosok gaib dan misterius, yang diikuti oleh berbagai ritual atau ritus dengan tujuan tertentu. ${ }^{37}$ Doreen Irvine, dalam buku, Menghancur-kan Ilmu Hitam menyatakan:

Dasar teologis pelayanan dalam praktek ocultisme hanyalah berpusat kepada kebenaran firman Allah yang hidup, kitab Ulangan 18:9-14

${ }^{37}$ Kurt Koch, Occult ABC, (Michigan: Grand Rapids, 1978), p. 207 menjelaskan tentang bagaimana larangan Allah terhadap segala praktek-praktek ocultisme karena perbuatan seperti itu merupakan kekejian bagi Allah (Ul. 18:12). Alkitab sangat jelas melarang setiap praktek ocultisme, karena perbuatan tersebut ialah tindakan berpaling dari Allah yang hidup dan merupakan kejahatan yang terbesar dari semua kejahatan. ${ }^{38}$

Jadi Alkitab dengan tegas melarang setiap orang untuk terlibat dalam praktik Okultisme; apapun alasan dan bentuknya. Alkitab dengan tegas melarang praktik yang demikian itu, sebagaimana tertulis:

Apabila engkau sudah masuk ke negeri yang diberikan kepadamu oleh TUHAN, Allahmu, maka janganlah engkau belajar berlaku sesuai dengan kekejian yang dilakukan bangsabangsa itu. Di antara-mu janganlah didapati seorangpun yang mempersembahkan anaknya laki-laki atau anaknya perempuan sebagai korban dalam api, ataupun seorang yang menjadi petenung, seorang peramal, seorang penelaah, seorang penyihir, seorang pemantera, ataupun seorang yang ber-tanya kepada arwah atau kepada roh peramal atau yang meminta petunjuk kepada orangorang mati. Sebab setiap orang yang melakukan hal-hal ini adalah kekejian bagi TUHAN, dan oleh karena kekejian-kekejian inilah TUHAN, Allah-mu, menghalau mereka dari hadapanmu. Haruslah engkau hidup dengan tidak bercela di hadapan TUHAN, Allahmu." (Ul. 18:9-13).

Pernyataan ayat Alkitab di atas harus menjadi pegangan setiap orang percaya sepanjang masa. Larangan dalam praktik okultisme diberikan

\footnotetext{
${ }^{38}$ Doreen Irvine, Menghancurkan Ilmu
} Hitam, (Yogyakarta: Yayasan Andi, 2003), h. 237 
kepada bangsa Israel, sebab mereka harus berbeda perilakunya dengan bangsa-bangsa lain yang tidak mengenal Allah. Lagi pula, praktek Okultisme akan mendatangkan hukuman dari Allah. J. D. Douglas, mengatakan bahwa:

Praktek okultisme melalui jimat digunakan untuk perlindungan dalam berperang, menyatakan atau menunjukkan kekuasaan, dan kepercayaan memakai jimat akan melindungi pemiliknya dari yang jahat. Biasanya jimat tersebut dipakai pada bagian kepala atau leher. $^{39}$

Pernyataan Douglas tersebut didukung oleh Suhandi Yeremia, dalam A Biblical Theology of the Old Testament, yang menyatakan bahwa Jenis jimat yang digunakan seperti tongkat, batu cadas, lembu emas, kain, gelang cincin (Yesaya 57:6). Keluaran 20:4-6 melarang manusia membuat berbagai bentuk patung yang menyerupai apapun karena itu sama halnya membatasi kuasa Allah dan menyembah kepada ilah-ilah lain atau kuasa gelap berarti tidak mengenal secara benar kedaulatan Tuhan sebagai Pencipta. ${ }^{40}$ Tentunya larangan untuk terlibat dalam kegiatan okultisme untuk menjaga kesucian hidup sebagai umat Tuhan.

c. Pertanyaan bagaimana peran aktif gereja dalam menangani praktik okultisme remaja di Gereja SidangSidang Jemaat Allah (GSJA) Wilayah Kabupaten Barito Timur Kalimantan Tengah.

\footnotetext{
${ }^{39}$ J. D. Douglas, Ensiklopedi Alkitab

Masa Kini Jilid I A-L, (Jakarta: Yayasan Komunikasi Bina Kasih/OMF, 2007), h. 487.

${ }^{40}$ Suhandi Yeremia, A Biblical Theology of the Old Testament, (Malang: Gandum Mas, 2005), h. 76.
}

Dari hasil penelitian ini terungkap bahwa $100 \%$ pendeta memahami tentang okultisme, namun hanya $70 \%$ yang mengajarkan hal-hal yang berkaitan dengan kuasa kegelapan itu. artinya para pendeta di lingkungan GSJA Wilayah Barito Timur belum sepenuhnya memberikan pengajaran mengenai bahaya okultisme. Pondsius dan Susanna Takaliuang, dalam buku Antara Kuasa Gelap dan Kuasa Terang, yang menyatakan bahwa Okultisme berarti ajaran, paham atau doktrin tentang hal-hal yang sifatnya rahasia, gelap, misterius dan tersembunyi, khususnya menyangkut kuasa gelap. ${ }^{41}$ Walaupun hal itu menyangkut kuasa gelap, namun pada kenyataannya ada orang yang terlibat di dalam praktik Okultisme tersebut, dan pada kenyataan-nya sekitar $33 \%$ remaja mengaku pernah terlibat dalam praktik Okultisme, padahal Alkitab dengan tegas menyatakan perlawanan terhadap berbagai bentuk Okultisme, sebagaimana yang dinyatakan berikut ini: Dan apabila orang berkata kepada kamu: "Mintalah petunjuk kepada arwah dan roh-roh peramal yang ber-bisik-bisik dan komatkamit," maka jawablah: "Bukankah suatu bangsa patut meminta petunjuk kepada allahnya? Atau haruskah mereka meminta petunjuk kepada orang-orang mati bagi orang-orang hidup?" (Yes. 8:19). Nabi Yesaya memberikan peringatan supaya orang percaya lebih mempercayai ke-hidupannya kepada Tuhan Allah. Alkitab menegaskan bahwa: Janganlah kamu melakukan telaah atau ramalan ... Jangan-lah kamu berpaling kepada arwah atau kepada rohroh peramal; janganlah kamu mencari mereka dan dengan demikian menjadi

$$
{ }^{41} \text { Pondsius dan Susanna Takaliuang, }
$$
Antara Kuasa Gelap dan Kuasa Terang, (Malang: Departemen Literatur YPPII, 2004, hlm.xvi. 
najis karena mereka; Akulah TUHAN Allahmu. (Imamat 19:26b,31). Warren W. Wiersbe, mengatakan bahwa: banyak orang akan terkejut pada saat mengetahui bahwa setanpun masuk gereja. Melalui kekuatan-kekuatan roh jahat, dia benar benar mengendalikan beberapa gereja. ${ }^{42}$

Perilaku orang percaya dalam men-jalani kehidupannya harusnya hanya ber-sama dengan Tuhan. J.W. Herfst dalam Nehemia Mimery pada buku Rahasia tentang Pengembalaan menyatakan bahwa tugas penggembalaan menolong orang satu persatu untuk menyadari hubungannya dengan Allah dan sesamanya dalam setuasi sendiri. ${ }^{43}$ Sekitar $70 \%$ para pendeta mengusulkan untuk memberikan masukan dan pengajaran-pengajaran rohani agar jemaat tidak tidak terjebak ke dalam okultisme. Pembinaan dilakukan dalam bentuk penjelasan bahwa praktik okultisme bertentangan dengan firman Tuhan dan jemaat harus berusaha terhindar dari tipu muslihat iblis. Jemaat juga dijelaskan tentang doktrin keselamatan untuk memberikan kepastian kepada jemaat dalam hidupnya di dunia ini dan di akhirat, sehingga mereka tidak perlu takut kepada roh-roh nenek moyang lagi.

Ada pembimbingan khusus supaya mereka yang terikat dapat lepas dari ikatan Iblis dan mengalami kemerdekaan serta keselamatan di dalam Yesus. Khusus bagi jemaat tertentu yang sudah terikat dalam Okultisme, para tokoh agama akan melakukan pelayanan pelepasan atau exorcism. Pelayanan Okultisme lebih banyak dilakukan

\footnotetext{
${ }^{42}$ Wiersbe Warren W. Strategi Setan, (Yogyakarta: Yayasan Andi, 1992), h. 139.

${ }^{43}$ Nehemia Mimery, Rahasia tentang Penggembalaan, (Jakarta: Mimery Press, tt.), h. 6.
}

kepada jemaat di luar gereja lokal. Pada saat dia ingin ikut Tuhan sungguhsungguh, roh-roh atau arwah akan melawan, sehingga harus dilakukan pelepasan. Biasa mereka atau pasien yang datang sendiri untuk dilayani. Biasanya mereka memakai jimat seperti: akar, pisau, keris, susuk atau minyakminyak yang pernah diminum. M. BonsStorm, dalam, Apakah Penggembalaan itu? Mengatakan bahwa:

Pastoral atau pengembalaan, atau kepemimpinan merupakan pekerjaan yang dikerjakan oleh satu orang yang biasa digelar Pastor atau Penatua atau Penilik Jemaat atau Gembala Sidang. Dan dari pendapat di atas ini pula penulis menyimpulkan bahwa tugas dan tanggung jawab seorang gembala adalah menjaga, membimbing, memelihara, merawat, me-nuntun, mengajak, mendisiplinkan dan menghibur domba-domba Allah yaitu jemaat Tuhan. Secara khusus dombadomba Allah atau jemaat Tuhan menghadapi musuhnya yaitu roh jahat yang disebut iblis dan setan, karena itu gembala menjaga jemaat Tuhan dari serangan Iblis, gembala membimbing jemaat Tuhan untuk membedakan pekerjaan roh kudus dan pekerjaan roh jahat dan memelihara jemaat sehingga tidak akan terpengaruh praktek-praktek okultisme. $^{44}$

Sebagian besar orang tua, yaitu sekitar 66,7\% menyatakan bahwa ada pembimbingan khusus bagi para remaja yang telah atau pernah terjerat dalam praktik okultisme. Cara-cara yang dilakukan gereja, seperti: Penjelasan mengenai bahaya dari penyembahan berhala (okultisme) yang disampaikan secara rinci, khususnya yang ada di

\footnotetext{
${ }^{44}$ M. Bons-Storm, Apakah
}

Penggembalaan itu? (Jakarta: BPK Gunung Mulia, 1988), h.19. 
dalam pe-nyembahan di kalangan suku Dayak Maanyan; Gereja melarang kita melaku-kan hal-hal yang bertentangan dengan Firman Tuhan, seperti: tidak boleh me-rokok, berjudi dan menyembah patung; Para orang tua juga diminta oleh gereja untuk melarang anak-anaknya agar tidak mengikuti praktik penyembahan berhala; Ada pembimbingan khusus, sehingga jemaat berani menolak ketika diberikan air untuk anak mereka yang sakit.

Jemaat juga diajar untuk mampu me-nolak ikut melakukan ritual yang ber-tujuan untuk menyembuhkan sakit atau memberi kebaikkan. Tujuan dari pem-bimbingan adalah agar jemaat mendapat pengetahuan tentang ajaran yang benar, dibimbing untuk dapat membedakan segala sesuatu dengan bijak berdasarkan kebenaran Firman Tuhan, sehingga mereka tidak terjerumus lagi ke dalam praktik okultisme, yang akan sangat me-rugikan jiwa mereka.

Jadi gereja-gereja yang tergabung dalam Gereja Sidang-Sidang Jemaat Allah (GSJA) Wilayah Kabupaten Barito Timur Kalimantan Tengah telah berupaya melakukan pembinaan rohani bagi anggota gereja, khususnya bagi para remaja tentang okultisme hal-hal buruk yang terkait di dalamnya.

\section{Kesimpulan Dan Saran}

\subsection{Kesimpulan}

Berdasarkan hasil penelitian yang dilakukan penelitia, maka diambil beberapa kesimpulan berikut ini, yaitu:

a. Gambaran praktik Okultisme dalam kehidupan masyarakat Dayak Maayan sudah tersusun sedemikian rupa karena hal tersebut merupakan bagian dari pola kehidupan yang diwariskan secara turun-temurun. Unsur-unsur Okultisme menjadi sangat kental karena tradisi tersebut merupakan budaya dan kepercayaan lama yang ada serta dilaksanakan turun-temurun. Beberapa hal yang menjadi nyata bahwa praktik okultisme dalam masyarakat Suku Dayak Maayan terus berlangsung adalah: orang yang men-jadi pemimpin dan dituakan, yaitu Balian, kemudian serangkaian upacara yang telah mendarahdaging dalam kehidupan masyarakat Dayak, seperti: Ipaket yaitu pemujaan kepada roh-roh nenek moyang, dan upacara kematian Marabia yaitu kegiatan mengantar arwah dari orang yang sudah meninggal dunia. Untuk upacara semacam ini, Pemerintah Kabupaten Barito Timur telah menjadikannya sebagai sarana untuk mempromosikan kebudayaan sehingga dalam beberapa kesempatan, justru upacara Marabia dibiayai oleh pemerintah setempat. Selain hal-hal di atas, ada juga halhal lain yang memiliki kaitan dengan Okultisme, yaitu: Memiliki ilmu kekebalan dan memberikan sesajen pada roh-roh di pohon-pohon besar, Melakukan pantangan-pantangan tertentu, karena larangan secara turun-temurun.

a. Masih ada remaja di Gereja SidangSidang Jemaat Allah (GSJA) Wilayah Kabupaten Barito Timur Kalimantan Tengah, yang terlibat dalam praktik Okultisme. Faktor lingkungan dan keluarga memberikan kontribusi besar bagi berlangsungnya praktik okultisme di kalangan remaja gereja. Data yang menunjukan bahwa 94,2\% remaja memahami dengan baik praktik-praktik okultisme di lingkungannya menjadi terbukti dengan adanya remaja gereja yang sampai penelitian ini ditulis masih 
terlibat praktik okultisme. Berbagai upacara adat dan tradisi keagamaan lama yang terus dilaksanakan secara turun-temurun telah memberi kontribusi besar bagi para remaja untuk terlibat dalam praktik berhala itu. artinya karena setiap saat ada pelaksanaan upacara adat Dayak Maayan, maka para remaja berinteraksi dengan hal-hal yang dimaksud; itulah sebabnya keterlibatan para remaja dalam praktik okultisme ini bukanlah sesuatu yang aneh.

b. Gereja Sidang-Sidang Jemaat Allah (GSJA) Wilayah Kabupaten Barito Timur Kalimantan Tengah, dapat mengupayakan pelayanan khusus bagi para remaja yang diduga terlibat dalam praktik Okultisme secara maksimal. Hal tersebut memungkinkan karena seluruh pendeta yang melayani di lingkungan GSJA Wilayah Kabupaten Bariot memahami dengan baik tentang halhal yang berkaitan dengan Okultisme. Dalam wawancara yang dilakukan terdapat fakta bahwa $70 \%$ para pendeta mengusulkan untuk memberikan masukan dan pengajaran-pengajaran rohani agar jemaat tidak tidak terjebak ke dalam okultisme.

Jadi gereja-gereja yang tergabung dalam Gereja Sidang-Sidang Jemaat Allah (GSJA) Wilayah Kabupaten Barito Timur Kalimantan Tengah telah berupaya me-lakukan pembinaan rohani bagi anggota gereja, khususnya bagi para remaja tentang okultisme hal-hal buruk yang terkait di dalamnya.

\subsection{Saran}

$\begin{array}{ccc}\text { Sebagaimana } & \text { yang } & \text { sudah } \\ \text { disebutkan di atas } & \text { bahwa } & \text { tujuan }\end{array}$

penelitian ini adalah: Untuk mengetahui praktik okultisme secara umum dalam kehidupan suku Dayak Maanyan; Untuk mengetahui praktik okultisme dikalangan remaja di Gereja SidangSidang Jemaat Allah (GSJA) Wilayah Kabupaten Barito Timur Kalimantan Tengah; dan Untuk me-ngetahui peran aktif gereja dalam me-nangani praktik okultisme pemuda remaja di Gereja Sidang-Sidang Jemaat Allah (GSJA) Wilayah Kabupaten Barito Timur Kalimantan Tengah, maka peneliti memberikan saran sebagai berikut:

a. Gereja harus lebih terbuka dan terarah serta bertanggungjawab dalam membina anggotanya supaya memiliki pengertian yang jelas tentang hal-hal yang berkaitan dengan praktik Okultisme. Pengertian yang dimaksud dapat dipergunakan sebagai alat untuk menghadapi dan mengatasi praktik okultisme di lingkungan gerejanya.

b. Bagi Universitas Kristen Indonesia, khususnya Program Pascasarjana, Prodi Magister Pendidikan Agama Kristen untuk mengkaji lebih mendalam lagi berkaitan dengan Pendidikan Agama Kristen (PAK) baik dilingkungan keluarga, gereja maupun dunia pendidikan; guna mencega praktik okultisme di kalangan remaja.

c. Penelitian ini dapat menjadi rujukan bagi para peneliti berikutnya, berkaitan dengan kajian praktek okultisme pada kalangan Suku Dayak.

\section{Daftar Pustaka}

Baswori dan Suwandi, Memahami

Penelitian Kualitatif, Jakarta: Rineka

Cipta, 1990. 
Bons-Storm. M., Apakah Penggembalaan itu? Jakarta: BPK Gunung Mulia, 1988.

Daradjat. Zakiyah, Membina Nilai-nilai Moral di Indonesia, Jakarta: Bulan Bintang, 1976.

Debra. Lardie, Concise Dictionary of The Occult and New Age, Grand Rapids: Kregel Publication, 1999.

Douglas. J. D., Ensiklopedi Alkitab Masa Kini Jilid I A-L, Jakarta: Yayasan Komunikasi Bina Kasih/OMF, 2007.

Gintings. E.P., Iblis dan Okultisme, Kabanjahe: GBKP, Abdi Karya, 2000.

Hadikusuma. Hilman, Antropologi Hukum Indonesia, Bandung: Alumni, 1986.

Hadiwijono. Harun, Religi Suku Murba di Indonesia, Jakarta: Gunung Mulia, 2003.

Hidayah. Zulyani, Ensiklopedia Suku Bangsa-bangsa di Indonesia, Jakarta: Yayasan Pustaka Obor Indonesia. 2015.

Hurlock. B. Elizabeth, Psikologi Perkembangan Suatu Pendekatan Sepanjang Rentang Kehidupan, Jakarta: Erlangga, 2002.

Irvine. Doreen, Menghancurkan Ilmu Hitam, Yogyakarta: Yayasan Andi, 2003.

Kertodipoero. Sarwoto, Kaharingan, Religi dan Penghidupan di Pehuluan Kalimantan, Bandung: Penerbitan Sumur, 1963.

Koch. Kurt, Occult ABC, Michigan: Grand Rapids, 1978.

Kruger. Th. Muller, Sejarah Gereja di Indonesia, Jakarta: BPK. Gunung Mulia, 1966.

Lerich. I. Christopher, The Occult Mind, Newyork: Cornel University, 2007.

Mimery. Nehemia, Rahasia tentang Penggembalaan, Jakarta: Mimery Press, tt.

Moleong J. Lexy, Metodologi Penelitian Kualitatif, Bandung: Remaja Rosdakarya, 2012.
Nazir. Abdul Nasir dan Abdul Muhith, Dasar-Dasar Keperawatan Jiwa Pengantar dan Teori. Jakarta: Salemba Medika, 2011.

Nazir. Muhammad, Metode Penelitian, Jakarta: Ghalia Indonesia, 1998.

Raco. J. R., Metode Penelitian Kualitatif, Jakarta: Grasindo, 2010.

Ryan. Neil Joseph, A History of Malaysia and Singapore, London: Oxford University Press. 1976.

Salam. Syamsir, Agama Kaharigan: AkarAkar Budaya Suku Dayak di Kalimantan Tengah, Jakarta: Lembaga Penelitian UIN Syarif Hidayatullah Jakarta, 2009.

Santrock. W. John, Perkembangan Anak, Jakarta: Erlangga, 2011.

Singarimbun. Masri dan Sofian Effendi (Ed), Metode Penelitian Survai, Jakarta: LP3LS, 1989.

Soekahar. H., Satanisme dalam Pelayanan Pastoral, Malang: Gandum Mas, 1983.

Soekanto. Soejono, Kamus Sosiologi, Jakarta: CV. Rajawali, 1983.

Sugiyono, Metode Penelitian Manajemen, Bandung: Alfabetta, 2016.

Sugiyono, Metode Penelitian Pendidikan, Pendekatan Kuantitatif, kualitatif dan $R \& D$, Bandung: Alfabeta, 2016.

Takaliuang. Pondsius dan Susanna, Antara Kuasa Gelap dan Kuasa Terang, Malang: Departemen Literatur YPPII, 2004.

Ukur. Fridolin, Tanya Jawab tentang Suku Dayak. Jakarta: BPK Gunung Mulia, 1977.

Umberen. M., Sejarah Kebudayaan Kalimantan, Jakarta: Penerbit Departemen Pendidikan Nasional, 1994.

Wiersbe W. Warren, Strategi Setan, Yogyakarta: Yayasan Andi, 1992.

Yeremia. Suhandi, A Biblical Theology of the Old Testament, Malang: Gandum Mas, 2005. 
Coomand. Mikhail, Manusia Daya: Dahulu, Sekarang, Masa Depan, Jakarta:

Gramedia 1987. diakses 26 April 2018 pukul 10.40 WIB,

https://koekoeh.wordpress.com/2012/ 04/30/mengenal-suku-bangsa-dayak/

https://id.wikipedia.org/wiki/Kalimantan_Te ngah, diakses pada hari Senin, 2 Juli 2018, Pkl. 15.35 WIB.

http://www.academia.edu/9006623/Makalah _Agama_Kaharingan, diunduh pada tanggal 4 Juni 2018, pukul 11.00 WIB.

Mirwaty, Budaya yang Tersembunyi di Indonesia, diakses pada tanggal 7 Maret 2018 pkl 15.25 WIB dari http://mirwaty.blogspot.co.id/2013/05 /budaya-yang-tersembunyi-diindonesia_11.html

http://www.academia.edu/9006623/Makalah _Agama_Kaharingan, diunduh pada tanggal 4 Juni 2018, pukul 11.00 WIB. 
